\title{
An unmetasomatized source for the Malaitan alnöite (Solomon Islands): Petrogenesis involving zone refining, megacryst fractionation, and assimilation of oceanic lithosphere
}

\author{
Clive R. Neal ${ }^{1}$ and Jon P. Davidson ${ }^{2, *}$ \\ 'Department of Geological Sciences, The University of Tennessee, Knoxville, TN 37996-1410, U.S.A. \\ ${ }^{2}$ Department of Geology, University of Michigan, Ann Arbor, MI 48109, U.S.A.
}

(Received April 14, 1988; accepted in revised form May 10, 1989)

\begin{abstract}
The Malaitan alnöite contains a rich and varied megacryst suite of unprecedented compositional range. We have undertaken trace element and isotope modeling in order to formulate a petrogenetic scheme which links the host alnöite to its entrained megacrysts. This requires that a proto-alnöite magma is the product of zone refining initiated by diapiric upwelling (where the initial melt passes through 200 times its volume of mantle). Isotopic evidence indicates the source of the proto-alnöite contains a timeintegrated LREE-depleted signature $\left({ }^{143} \mathrm{Nd} /{ }^{144} \mathrm{Nd}=0.51274\right)$. Impingement upon the rigid lithosphere halts or dramatically slows the upward progress of the mantle diapir. At this point, the magma cools and megacryst fractionation begins with augites crystallizing first, followed by subcalcic diopsides and finally phlogopites. Garnet probably crystallizes over the entire range of clinopyroxene fractionation. Estimated proportions of fractionating phases are $30 \%$ augite, $24.5 \%$ subcalcic diopside, $27 \%$ garnet, $12.9 \%$ phlogopite, $5 \%$ bronzite, $0.5 \%$ ilmenite, and $0.1 \%$ zircon. As this proto-alnöite magma crystallizes, it assimilates a subducted component of seawater-altered basalt which underplates the Ontong Java Plateau. This is witnessed in the isotopic composition of the megacrysts and alnöite.
\end{abstract}

\section{INTRODUCTION}

MANTLE-DERIVED MAGMAS, which are explosively erupted to the Earth's surface, contain invaluable samples of the lithospheric and asthenospheric mantle. The presence of monomineralic discrete nodule (BOYD and NIXON, 1973; NIXON and BOYD, 1973a) or megacryst suites (DAwSON, 1980 ) in these mantle-derived, silica undersaturated magmas is common. However, the relationship of megacrysts to the host magma is unclear. Compositional variations exhibited by members of this suite suggest that they represent a series of crystals precipitating from a single parental magma. IRVING (1974) and BOYD and NIXON (1975) believed this parental melt is unrelated to the magma in which they are ultimately entrained. GURNEY et al. (1979) and HARTE and GURNEY (1981) concluded the megacrysts are products of isobaric crystallization from a "proto-kimberlite" magma, and MitCHELL $(1977,1979)$ advocated a cognate high-pressure origin. SCHULZE and HoOVER (1982) and SCHULZE (1984) demonstrated the dependence of fractionation trends within megacryst suites on the bulk composition of the magma system and the proportions of crystallizing phases. HUNTER and TAYLOR (1984) and SHERVAIS et al. (1987) argued for generation of $\mathrm{Cr}$-rich and $\mathrm{Cr}$-poor megacrysts by a process of magma mixing in the low velocity zone. These authors envisage the low velocity zone to contain discrete magma bodies representing various stages of high-pressure crystallization of kimberlite melts. However, the classification of megacrysts as cognate or xenocrystal remains one of the unresolved problems in mantle petrology.

The source composition of mantle-derived magmas is also difficult to determine. This problem is compounded because

\footnotetext{
* Present address: Department of Earth and Space Sciences, University of California, Los Angeles, CA 90024, U.S.A.
}

of problems in distinguishing between xenolithic, xenocrystal, and phenocrystal material in the kimberlite matrix (NIXON and BOYD, 1973b; MITCHELL, 1986). Experimental evidence suggests a carbonated peridotite source for mantle-derived magmas containing either phlogopite, amphibole, or both minerals (e.g., FRANZ, 1965; EGGLER, 1978; OLAFSSON and EGGLER, 1983; TAYLOR and GREEN, 1986; WYLLIE, 1980, $1986,1987)$. However, the observed presence of primary carbonate in mantle peridotites is rare (MCGETCHIN and BESANCON, 1973). The concept of a metasomatically enriched source region is now widely accepted (e.g., KAY and GAST, 1973; LlLOY and BAILEY, 1975; MENZIES and MURTHY, 1980; BAlLEY, 1982, 1984; FRASER et al., 1985; MENZIES and HAWKESWORTH, 1987). Such an enrichment process is invoked in order to account for the high abundances of trace elements in these mantle-derived magmas.

The object of this paper is to present a model formulated from the interpretation of geochemical data for host volcanic and megacryst petrogenesis. Questions to be addressed are: (1) Is a metasomatized source required for alnöite petrogenesis? (2) Is the Malaitan alnöite a primary mantle melt? (3) Is there a relationship between the host alnöite and the entrained megacryst suite? Interpretation of $\mathrm{Sr}, \mathrm{Nd}$, and $\mathrm{O}$ isotopic and trace element data of the host alnöite and megacryst suite allows the formulation of an integrated model for megacryst and alnöite petrogenesis.

\section{GEOLOGICAL SETTING}

The Solomon Islands chain delineates the boundary between the Pacific and Indo-Australian plates. The area is dominated by the Ontong Java Plateau (OJP), which is a vastly overthickened portion of oceanic crust (up to $42 \mathrm{~km}$-COLEMAN, 1976; Hussong et al., 1979) abutting the Indo-Australian plate (Fig. 1). The OJP has similar seismic velocities to that of normal oceanic crust, but each layer is abnormally thickened (FUROMOTo et al., 1976). However, CARLSON et al. (1980) suggested that this interpretation is too simplistic and 


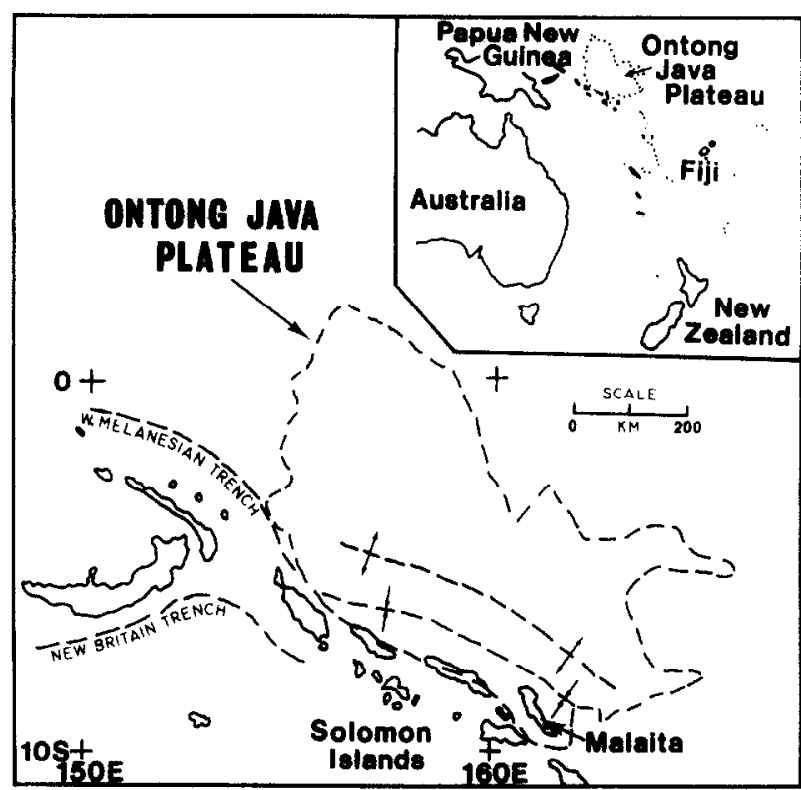

FIG. 1. Tectonic sketch map of the SW pacific region.

that at least the central part of the OJP is of continental affinity. Seismic refraction studies indicate the presence of a high velocity $(7.6 \mathrm{~km} / \mathrm{sec}$ ) basal crustal layer (FurOMOTO et al., 1976; HUSSONG et al., 1979). NIXON and COLEMAN (1978) suggested that this layer comprises garnet granulite and have argued for the continental affinity of the OJP. HouTZ and EwING (1976) and HUSSONG et al. (1979) concluded that this layer represents oceanic basalts or serpentinized peridotites, respectively, whereas NEAL and TAYLOR (1989) suggested the OJP is underplated by a subducted derivative of oceanic crust.

The island of Malaita is geologically distinct from other islands in the Solomons chain, as it is formed from the obducted leading edge

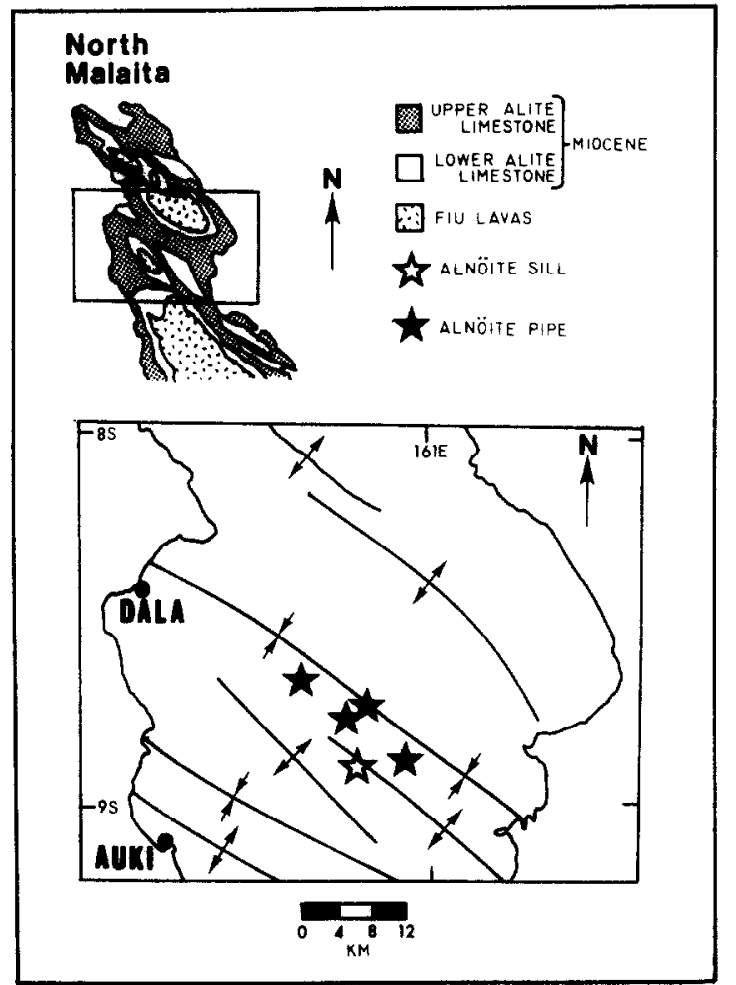

FIG. 2. Location map and general geology of northern Malaita. of the OJP. The identification of ultrabasic rocks in streams from central north Malaita in 1951 (RICKWOOD, 1957) led to a fruitless search for diamonds by THOMPSON (1965) and GERRYTS (1965). Six samples of these rocks were collected and subsequently described as alnöites by ALLEN and DEANS (1965). The term alnöite was used by ROSENBUSCH (1887) for a suite of dike rocks found on the island of Alnö, off the coast of Sweden. Rock (1986) has defined alnöites as ultramafic lamprophyres with essential melilite, but with no feldspar.

Pipe-like bodies of alnöite were explosively emplaced in limestones and mudstones which have been folded into NW-SE trending anticlines and synclines (RICKWOOD, 1957; Fig. 2). The pipes at Babaru'u and Kwaikwai have a core of tine-grained, black alnöite containing megacrysts, surrounded by an autolithic ( $f$., DANCHIN et al., 1975) breccia containing xenoliths of peridotite and country rock. macrocrysts, and megacrysts.

\section{THE ALNÖITE}

The Malaitan alnöite is silica undersaturated (35.7-36.4 wt $\left.\% \mathrm{SiO}_{2}\right)$, being olivine and nepheline normative. Only fresh samples were analyzed, and during sample preparation care was taken to exclude contained megacrysts (see Appendix for analytical methods). In general, the Malaitan alnöite is extremely rich in $\mathrm{Mg}(\mathrm{MgO}=18.0-25.1$ $w t \% ; \mathrm{Mg}^{2}=73-79$ : Table 1) and alkalis, especially $\mathrm{K}_{2} \mathrm{O}$, which is a function of phlogopite in the groundmass (NIXON et al., 1980). The alnöite is also rich in volatile components, as the loss on ignition is $\cong 5 \%$.

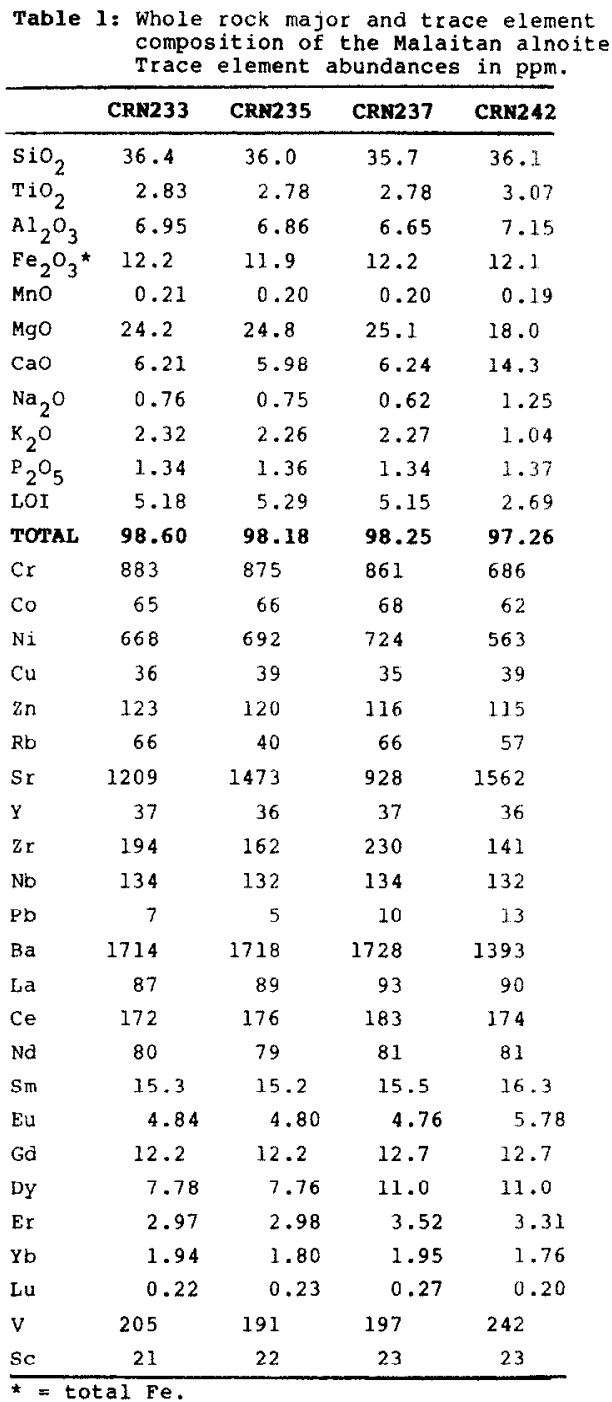


The Ba (1393-1728 ppm) and $\mathrm{Sr}$ (928-1562 ppm) abundances (Table 1) are in excess of those found in Group 1 kimberlites and alkali basalts (MITCHELl, 1986; BASALTIC VOLCANISM STUDY PROJECT, 1981). However, the $\mathrm{Rb} / \mathrm{Sr}$ ratio of the Malaitan alnöite $(\cong 0.044)$, and $\mathrm{Ni}$ and $\mathrm{Sc}$ abundances are intermediate between alkali basalt and kimberlite, whereas $\mathrm{Zr}, \mathrm{Cr}$, and $\mathrm{Co}$ abundances are similar to those in Group 1 kimberlites. The relatively low levels of $\mathrm{Zr}$ (141$230 \mathrm{ppm}$ ) may indicate some zircon fractionation. $\mathrm{Nb}$ is present at higher than usual abundances for within-plate volcanic rocks (PEARCE and CANN, 1973; NORRY and FITTON, 1983; COX, 1983). However, while $\mathrm{Nb}$ abundances are higher than in alkali basalts, they are similar to those in kimberlite.

The Malaitan alnoite is LREE enriched $(\mathrm{La} \cong 300$ times chondrite; Table 2 and Fig. 3a). Four samples were analyzed for the REE and patterns are parallel $(\mathrm{La} / \mathrm{Yb}=45.0-56.8)$. All show a slight positive Eu anomaly $\left(\mathrm{Sm}_{\mathrm{N}} / \mathrm{Eu}_{\mathrm{N}} \cong 1.2, \mathrm{~N}=\right.$ chondrite normalized). The Malaitan alnöite REE pattern (Fig. 3a) is intermediate $(\mathrm{La} / \mathrm{Yb} \cong 47)$ between alkali basalt $(\mathrm{La} / \mathrm{Yb} \cong 17)$ and Group 1 kimberlites $(\mathrm{La} / \mathrm{Yb}$ $\cong 125$ ).

\section{THE MEGACRYST SUITE}

The Malaitan alnöite contains a rich and varied suite of megacrysts which have similar compositions to those found in kimberlites. Large garnet (up to $8.2 \mathrm{~kg}$ ) and subcalcic diopside (up to $2.5 \mathrm{~kg}$ ) megacrysts are common. Also present are clinopyroxene-ilmenite intergrowths, bronzite, ilmenite, phlogopite, and minor zircon (NIXON, 1980). Augite megacrysts are also found, akin to megacryst suites from alkali basalts, demonstrating the transitional nature of the alnöite. Olivine is not found as a megacryst phase at Malaita. Major elements were analyzed by electron microprobe and the REE by solid source mass spectrometry (see Appendix for methods).

\section{Clinopyroxene megacrysts}

The occurrence of augites in this megacryst suite gives an extremely large range in clinopyroxene compositions (Fig. 4; Table 3) practically unparalleled in megacryst suites from kimberlite or alkali basalt. There is a progressive increase in $\mathrm{Ca} /(\mathrm{Ca}+\mathrm{Mg})$ and sympathetic decrease in $\mathrm{Mg} /(\mathrm{Mg}+\mathrm{Fe})$ or $\mathrm{Mg} \#(\mathrm{Fe}=$ total iron $)$ from the subcalcic diopsides to the augite megacrysts, with the clinopyroxene-ilmenite intergrowths always intermediate (Fig. 4; Table 3). This correlation is usually interpreted as a decreasing equilibration temperature, using the diopsideenstatite solvus (e.g., LINDSLEY and DIXON, 1976; LINDSLEY and ANDERSEN, 1982). The continuous correlation suggests all three clinopyroxene types crystallized from a single evolving magma. There is a decrease in $\mathrm{Na}_{2} \mathrm{O}$ and $\mathrm{TiO}_{2}$ from the augites to the subcalcic diopsides, with clinopyroxene-ilmenite intergrowths again being intermediate for $\mathrm{Na}$ but containing similar $\mathrm{TiO}_{2}$ abundances to the augites (Fig. 5). Chromium is only present in appreciable amounts in the subcalcic diopsides. $\mathrm{SiO}_{2}$ and $\mathrm{Al}_{2} \mathrm{O}_{3}$ are generally constant throughout all three groups. The high $\mathrm{Al}_{2} \mathrm{O}_{3}$ content of the clinopyroxene megacrysts, relative to those found in kimberlite, is probably a result of a lower pressure of equilibration (e.g., MACGREGOR, 1974; AKELLA, 1976), but may be related to the high jadeite components of these clinopyroxene megacrysts (e.g., YODER and TILLEY, 1962; KUSHIRO, 1979). The high jadeite component of these megacrysts (Table 3 ) indicates a relatively high pressure of crystallization ( $\mathrm{KU}-$ SHIRO, 1979).

Six subcalcic diopside and six augite megacrysts were analyzed for the REE (Table 2; Fig. 3b). Both the subcalcic diopsides and augites have LREE-enriched profiles which are convex upwards, with a maximum at $\mathrm{Sm}$ and Eu, respectively (NIXON and NEAL, 1987). Both groups have REE abundances up to 10 times chondrite in the middle REE (MREE). The augite megacrysts have generally lower $\mathrm{La} / \mathrm{Yb}$ ratios $(3.83-4.36)$ than the subcalcic diopsides $(4.25-6.38)$.

\section{Garnet megacrysts}

There is a lack of major compositional variation in the Malaitan garnet megacrysts (Fig. 4; Table 4) and only a slight variation in $100 \cdot[\mathrm{Mg} /(\mathrm{Mg}+\mathrm{Fe})](71.7$ to 77.3$)$. The $100 \cdot[\mathrm{Ca} /(\mathrm{Ca}+\mathrm{Mg})]$ ratio is approximately constant $(14.0-15.4)$, consistent with the buffering effect of clinopyroxene and orthopyroxene crystallization. Unlike kimberlitic garnet megacrysts from Monastery Mine (GURNEY et al., 1979), $\mathrm{Cr}_{2} \mathrm{O}_{3}$ does not increase with $\mathrm{Mg} \#$, and varies only from $0.03-$ $0.25 \mathrm{wt} \%$. $\mathrm{MnO}$ and $\mathrm{TiO}_{2}$ remain constant throughout the suite at approximately $0.3 \mathrm{wt} \%$.

\begin{tabular}{|c|c|c|c|c|c|c|c|c|c|c|}
\hline Samele & La. & ce & wa & $\mathrm{Sm}$ & En & Gd & Dy & Ex & $\mathbf{X b}$ & Iu \\
\hline & \multicolumn{10}{|c|}{ SOBCALCIC DIOPSIDES } \\
\hline CRN150 & 1.86 & 5.90 & 5.74 & 1.88 & 0.69 & 2.12 & 1.67 & 0.66 & 0.39 & 0.05 \\
\hline CRN158 & 1.35 & 4.82 & 5.01 & 1.66 & 0.60 & 1.85 & 1.39 & 0.53 & 0.31 & 0.04 \\
\hline CRN183 & 1.36 & 4.78 & 4.98 & 1.68 & 0.59 & 1.84 & 1.25 & 0.39 & 0.32 & 0.03 \\
\hline CRN198 & 0.51 & 1.64 & 1.70 & 0.56 & 0.20 & 0.60 & 0.45 & 0.16 & 0.08 & 0.01 \\
\hline CRN199 & 1.65 & 5.89 & 6.32 & 2.15 & 0.80 & 2.40 & 1.77 & 0.61 & 0.32 & 0.04 \\
\hline CRN200 & 1.70 & 5.85 & 6.25 & 2.12 & 0.78 & 2.38 & 1.76 & 0.61 & 0.33 & 0.04 \\
\hline \multicolumn{11}{|c|}{ AUgITES } \\
\hline PHN3517 & 1.34 & 5.19 & 5.83 & 2.03 & 0.75 & 2.29 & 1.76 & 0.59 & 0.31 & 0.03 \\
\hline PHN3889 & 1.38 & 5.26 & 5.97 & 2.11 & 0.78 & 2.40 & 2.17 & 0.63 & 0.33 & nd \\
\hline PHN3901 & 1.26 & 5.14 & 6.09 & 2.18 & 0.81 & 2.44 & 1.85 & 0.60 & 0.32 & 0.03 \\
\hline PHN3905 & 1.34 & 5.51 & 6.70 & 2.38 & 0.87 & 2.64 & 1.98 & 0.66 & 0.35 & 0.04 \\
\hline PHN3913 & 1.31 & 5.02 & 5.69 & 2.03 & 0.74 & 2.32 & 1.74 & 0.59 & 0.30 & 0.03 \\
\hline PHN3967 & 1.19 & 4.89 & 5.81 & 2.06 & 0.77 & 2.32 & 1.72 & 0.60 & 0.31 & nd \\
\hline \multicolumn{11}{|c|}{ GARNETS } \\
\hline CRN60 & 0.06 & 0.25 & 0.88 & 1.02 & 0.61 & 2.95 & 6.11 & 4.71 & 4.60 & 0.68 \\
\hline CRN61 & 0.02 & 0.17 & 0.86 & 1.04 & 0.66 & 3.14 & 6.17 & 4.74 & 4.44 & 0.72 \\
\hline CRN 131 & 0.02 & 0.19 & 0.88 & 1.01 & 0.62 & 2.91 & 6.23 & 4.73 & 4.51 & 0.66 \\
\hline CRN135 & 0.03 & 0.19 & 0.87 & 1.01 & 0.62 & 2.90 & 5.15 & 4.82 & 4.07 & 0.63 \\
\hline CRN136 & 0.02 & 0.15 & 0.71 & 0.88 & 0.55 & 2.96 & 6.45 & 4.28 & 4.17 & 0.64 \\
\hline CRNI 45 & 0.02 & 0.16 & 0.85 & 1.03 & 0.63 & 3.17 & 5.50 & 4.94 & 5.04 & 0.76 \\
\hline \multicolumn{11}{|c|}{ PBLOCOP ITE } \\
\hline CRN124 & 1.13 & 2.21 & 0.98 & 0.19 & 0.07 & 0.17 & 0.14 & 0.04 & 0.03 & nd \\
\hline
\end{tabular}

nd $=$ not detected. 

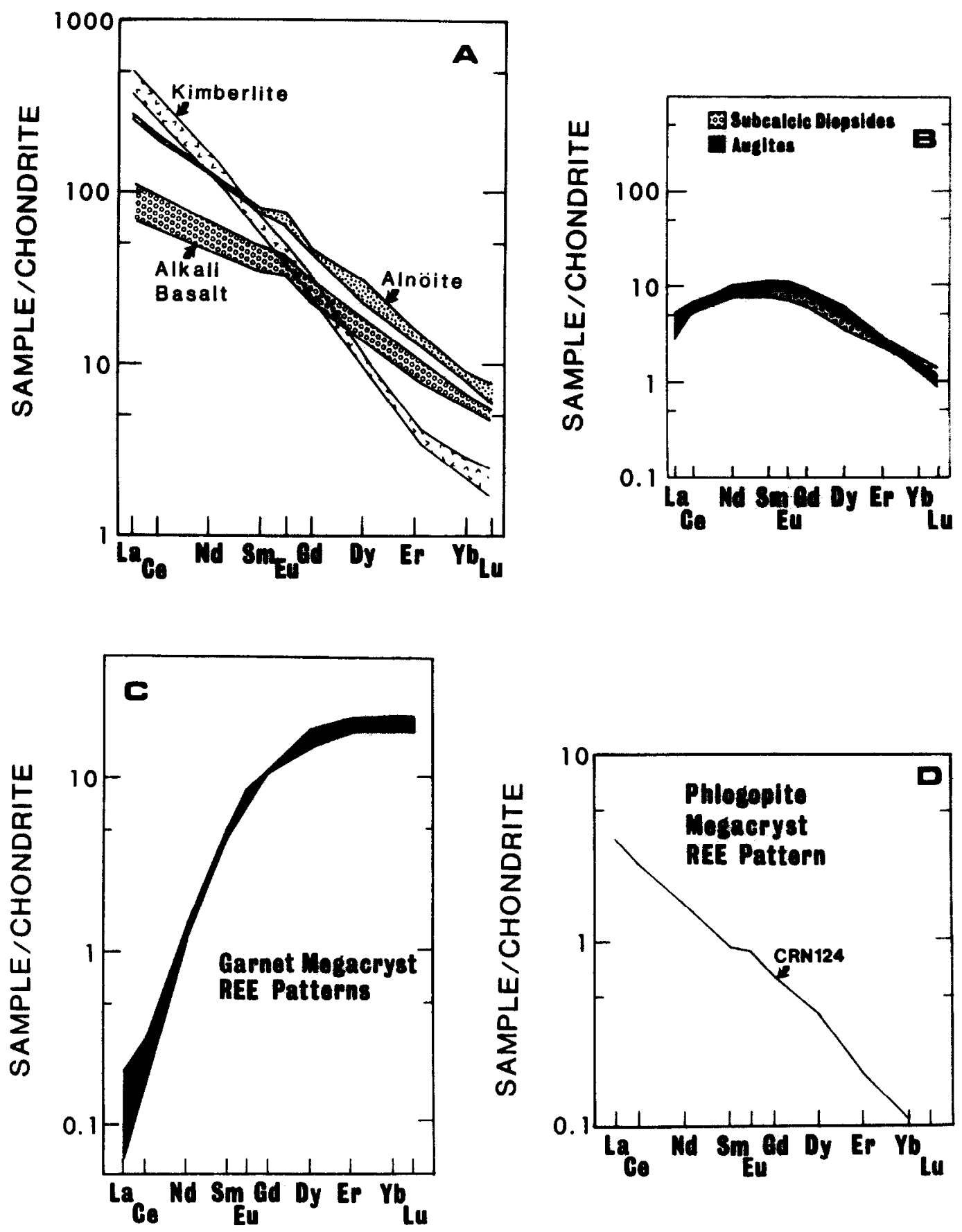

FIG. 3. Chondrite-normalized REE patterns of (A) the host alnöite; (B) the augite and subcalcic diopside megacrysts; (C) the garnet megacrysts; (D) a phlogopite megacryst. Representative alkali basalt from FREY et al. (1978); representative kimberlite from JONES (1984) and MITCHELL (1986).

The REE abundances of six analyzed Malaitan garnet megacrysts are given in Tablc 2 and Fig. 3c. They are typically LREE-depleted (La approximately $0.1 \cdot$ chondrite) with the HREE enriched up to 20 times chondrite (NIXON and NEAL, 1987). The six show remarkably little variation, in common with their major element chemistry.

\section{Orthopyroxene megacrysts}

The orthopyroxene or bronzite megacrysts show slight variation in $\mathrm{Mg}$ \# from 85.7 to 87.3 and have constant $\mathrm{Ca} /(\mathrm{Ca}+\mathrm{Mg})$ ratios
(Fig. 4). All other elements are approximately constant. Data for the Malaitan bronzite megacrysts are from NIXON and BOYD (1979).

\section{Clinopyroxene-ilmenite intergrowths and ilmenite megacrysts}

Ilmenites from clinopyroxene-ilmenite intergrowths are homogeneous throughout each specimen and within individual lamellae (Table 5). Discrete ilmenite megacryst compositions overlap those from the intergrowths (Fig. 6) and as with clinopyroxene megacrysts, probably represent a continuous crystallization sequence. The discrete 


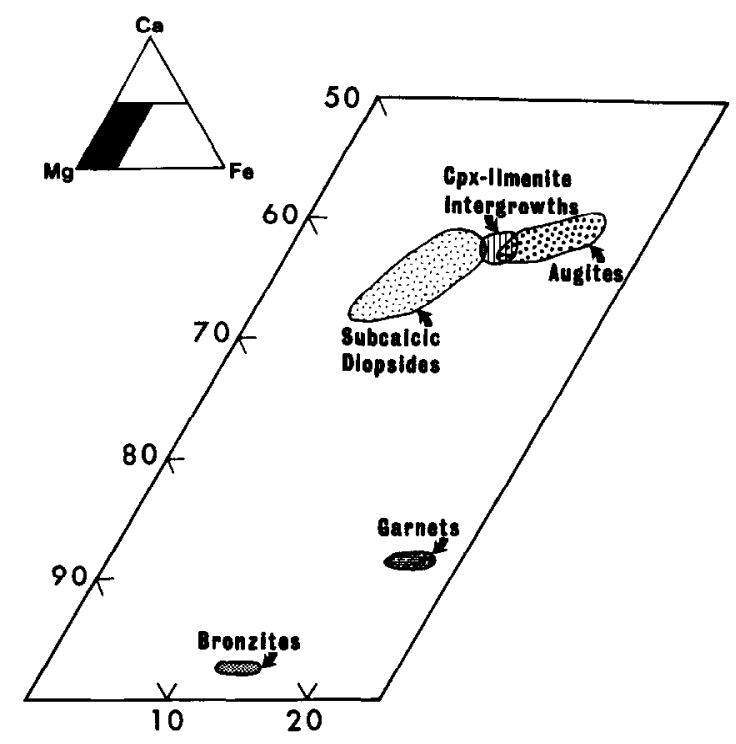

FIG. 4. Compositions of clinopyroxene, garnet, and bronzite megacrysts represented on a $\mathrm{Ca}-\mathrm{Mg}-\mathrm{Fe}$ diagram.

ilmenites have a higher $\mathrm{FeTiO}_{3}$ component. $\mathrm{Fe}^{3+}$ was calculated stoichiometrically and is approximately $10 \%$ in the intergrowths, but increases slightly in the discrete ilmenites. $\mathrm{Al}_{2} \mathrm{O}_{3}$ is relatively constant $(0.5-0.9 \mathrm{wt} \%)$ in both groups (Table 5). Three discrete ilmenites (CRN63A-C) display titano-magnetite spinel exsolution. These spinels are rich in $\mathrm{Fe}^{2+}, \mathrm{Fe}^{3+}$, and $\mathrm{Al}$ relative to ilmenite (NEAL, 1985). This ilmenite-spinel exsolution relationship is similar to that described by PASTERIS et al. (1979) from the Frank Smith Mine, South Africa; HAGGERTY et al. (1979) from the Monastery Mine, South Africa; and by LEBLANC $e t$ al. (1982) from southern Algeria. It is attributed to recrystallization and exsolution in response to the stress imposed during conduit formation (PASTERIS et al., 1979).

\section{Phlogopite megacrysts}

Three phlogopite megacrysts have been analyzed (Table 6) and there is little compositional variation between them. They all fall into the low-Cr, high-Ti group defined by DAwson et al. (1978). These authors argued that the phlogopite megacrysts have crystallized from the alnöite just prior to eruption, on the basis of high $\mathrm{Al}_{2} \mathrm{O}_{3}$ contents in both the phlogopites and alnöite. These phlogopites clearly testify to the presence of water in the magma from which they crystallized.

One phlogopite megacryst was analyzed for REE (Table 2; Fig. 3d). It is LREE-enriched with a maximum at $\mathrm{La}$, although all REE abundances are low $(\mathrm{La}=3.5 \cdot$ chondrite; $\mathrm{Yb}=0.1 \cdot$ chondrite $)$. There is a slight positive Eu anomaly present.

\section{ISOTOPE GEOCHEMISTRY}

\section{Neodymium and strontium}

Determination of the ${ }^{87} \mathrm{Sr} /{ }^{86} \mathrm{Sr}$ and ${ }^{143} \mathrm{Nd} /{ }^{144} \mathrm{Nd}$ isotope ratios were carried out on the augite, subcalcic diopside, garnet, and phlogopite megacrysts and the host alnöite. The garnet megacrysts were not analyzed for $\mathrm{Sr}$ isotopes, and the phlogopite megacrysts were not analyzed for Nd because of very low $\mathrm{Sr}$ and $\mathrm{Nd}$ abundances, respectively. There is a general correlation between $\mathrm{Sr}$ and $\mathrm{Nd}$ isotope systematics (Table 7; Fig. 7), with the augite megacrysts having the least radiogenic isotopic ratios $(0.703223-0.703618$ and 0.512725 0.512785 ). There is a progressive increase in ${ }^{87} \mathrm{Sr} /{ }^{86} \mathrm{Sr}$ and ${ }^{143} \mathrm{Nd}$ / ${ }^{144} \mathrm{Nd}$ ratios from the augites to the subcalcic diopsides $(0.70366 \mathrm{I}$ 0.704051 and $0.512759-0.512815$ ), to the phlogopite megacrysts $(0.703736-0.704203)$, to the host alnöite $(0.704207-0.704645$ and $0.512764-0.512852)$. The garnet megacrysts $(0.512727-0.512843)$ practically span the entire range defined by these three groups. However, the average garnet megacryst ${ }^{143} \mathrm{Nd} /{ }^{144} \mathrm{Nd}$ ratio is intermediate to that of the augite and subcalcic diopside megacrysts. The augites contain lower strontium abundances (27.2-32.2 ppm) compared with the subcalcic diopsides $(67.5-87.0 \mathrm{ppm})$.

\section{Oxygen}

Six augite and five subcalcic diopside megacrysts were analyzed (Table 7) for oxygen isotopes. The subcalcic diopsides have a restricted oxygen isotopic composition, $\delta^{18} \mathrm{O}$ ranging from +5.9 to $+6.1 \%$. However, the augite megacrysts show a much larger range, which encompasses that of the subcalcic diopsides $\delta^{18} \mathrm{O}=+5.9$ to $17.3 \%$ ). Both of these populations are within the range of $\delta^{18} \mathrm{O}$ values reported in mantle xenoliths from Hawaii $(+5.2$ to $+7.2 \%$; KYSER et al., $1981)$ and in ocean island basalts (+4.8 to $+7.5 \%$; KYSER $e t$ al., 1982).

Table 3: Representative analyses of the clinopyroxene megacrysts.

\begin{tabular}{|c|c|c|c|c|c|c|}
\hline & \multicolumn{6}{|c|}{ SUBCALCIC DIOPSIDES } \\
\hline & CRN150 & CRN158 & CRN183 & CRN198 & CRH199 & CRw200 \\
\hline $\mathrm{SiO}_{2}$ & 53.1 & 53.0 & 52.8 & 53.0 & 52.8 & 53.0 \\
\hline $\mathrm{TiO}_{2}$ & 0.64 & 0.61 & 0.70 & 0.71 & 0.88 & 0.75 \\
\hline $\mathrm{Al}_{2} \mathrm{O}_{3}$ & 5.72 & 5.10 & 5.15 & 5.87 & 5.27 & 5.83 \\
\hline $\mathrm{Cr}_{2} \mathrm{O}_{3}$ & 0.13 & 0.30 & 0.27 & 0.10 & nd & 0.09 \\
\hline $\mathrm{FeO}^{*}$ & 6.66 & 5.66 & 5.85 & 5.92 & 6.74 & 6.05 \\
\hline Mno & 0.17 & 0.12 & 0.12 & 0.13 & 0.10 & 0.14 \\
\hline $\mathrm{NgO}$ & 16.6 & 17.3 & 17.2 & 16.7 & 15.7 & 16.9 \\
\hline $\mathrm{CaO}$ & 14.2 & 15.5 & 15.3 & 15.5 & 15.9 & 15.3 \\
\hline $\mathrm{Na}_{2} \mathrm{O}$ & 2.44 & 2.10 & 2.25 & 1.99 & 2.21 & 2.18 \\
\hline TOTAL & 99.62 & 99.69 & 99.64 & 99.92 & 99.60 & 100.24 \\
\hline Fs & 12.2 & 10.0 & 10.4 & 10.7 & 12.2 & 10.9 \\
\hline En & 54.3 & 54.8 & 54.7 & 53.6 & 50.8 & 54.0 \\
\hline Wo & 33.5 & 35.2 & 34.9 & 35.7 & 37.0 & 35.1 \\
\hline
\end{tabular}

CLIKOPYROXENE-ILABNITE IKTERGROATHS

\begin{tabular}{|c|c|c|c|c|c|c|}
\hline & PEN3865 & PHN3866 & PEN3867 & PHN3869 & PBN3870 & PHN39 \\
\hline$\overline{\mathrm{SiO}_{2}}$ & 52.5 & 52.9 & 52.0 & 52.3 & 53.7 & 52.3 \\
\hline $\mathrm{TiO}_{2}$ & 0.96 & 0.62 & 1.04 & 0.63 & 0.96 & 0.92 \\
\hline $\mathrm{Al}_{2} \mathrm{O}_{3}$ & 4.83 & 4.89 & 2.85 & 4.84 & 4.91 & 4.86 \\
\hline $\mathrm{Cr}_{2} \mathrm{O}_{3}$ & 0.01 & 0.01 & nd & nd & nd & nd \\
\hline $\mathrm{FeO}$ & 8.07 & 8.23 & 7.34 & 7.95 & 8.07 & 7.70 \\
\hline MnO & 0.14 & 0.14 & 0.14 & 0.14 & 0.13 & 0.13 \\
\hline $\mathrm{MgO}$ & 14.0 & 14.1 & 14.9 & 14.3 & 14.3 & 15.1 \\
\hline $\mathrm{CaO}$ & 16.0 & 15.8 & 20.3 & 15.8 & 16.0 & 16.0 \\
\hline $\mathrm{Na}_{2} \mathrm{O}$ & 2.68 & 2.65 & 1.16 & 2.42 & 2.48 & 2.52 \\
\hline TOTAL & 99.19 & 99.34 & 99.73 & 98.38 & 100.55 & 99.53 \\
\hline Fs & 15.1 & 15.3 & 12.3 & 14.8 & 14.9 & 14.0 \\
\hline En & 46.6 & 47.0 & 44.3 & 47.5 & 47.1 & 48.9 \\
\hline Wo & 38.3 & 37.7 & 43.4 & 37.7 & 38.0 & 37.1 \\
\hline
\end{tabular}

total Fe.

\begin{tabular}{|c|c|c|c|c|c|c|}
\hline \multicolumn{7}{|c|}{ ADGITES } \\
\hline & PEN3871 & PHN3889 & PEN3901 & PBN3905 & PHN3913 & PHN396 \\
\hline $\mathrm{SiO}_{2}$ & 54.0 & 52.3 & 52.6 & 52.0 & 52.6 & 53.0 \\
\hline $\mathrm{TiO}_{2}$ & 0.89 & 0.81 & 0.87 & 0.82 & 1.03 & 0.75 \\
\hline $\mathrm{Al}_{2} \mathrm{O}_{3}$ & 5.79 & 4.75 & 4.91 & 5.75 & 5.72 & 4.96 \\
\hline $\mathrm{Cr}_{2} \mathrm{O}_{3}$ & nd & 0.02 & nd & nd & nò & nd \\
\hline $\mathrm{FeO}_{\star}$ & 10.0 & 8.82 & 9.07 & 10.0 & 8.98 & 9.60 \\
\hline MnO & 0.16 & 0.15 & 0.15 & 0.15 & 0.15 & 0.15 \\
\hline $\mathrm{MgO}$ & 10.8 & 13.2 & 13.6 & 10.9 & 12.6 & 12.1 \\
\hline $\mathrm{CaO}$ & 15.1 & 15.0 & 14.8 & 15.6 & 15.0 & 15.2 \\
\hline $\mathrm{Na}_{2} \mathrm{O}$ & 4.12 & 3.41 & 3.35 & 4.41 & 3.88 & 3.91 \\
\hline TOTAL & 100.86 & 98.46 & 99.35 & 99.63 & 99.96 & 99.67 \\
\hline Fs & 20.6 & 17.1 & 17.4 & 20.3 & 17.8 & 19.0 \\
\hline En & 39.7 & 45.7 & 46.3 & 39.3 & 44.3 & 42.7 \\
\hline Wo & 39.7 & 37.2 & 36.3 & 40.4 & 37.9 & 38.3 \\
\hline
\end{tabular}




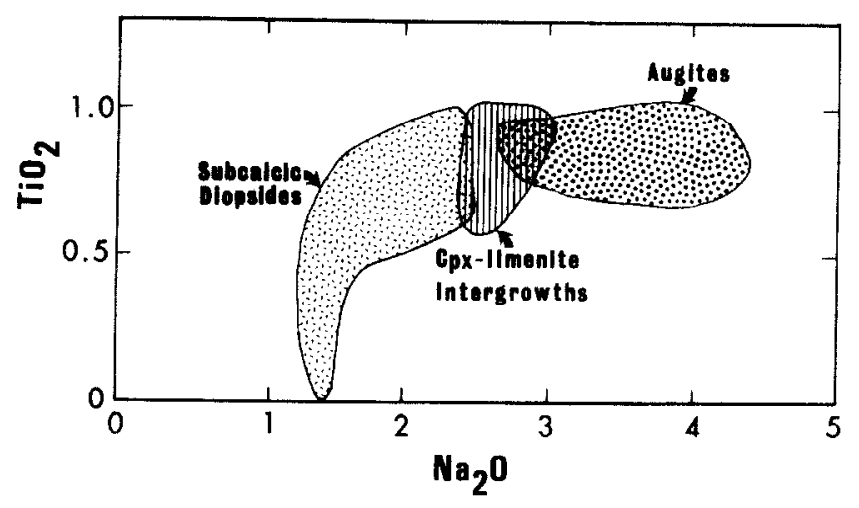

FiG. 5. A plot of $\mathrm{Na}_{2} \mathrm{O} v s . \mathrm{TiO}_{2}$ for the clinopyroxene megacrysts. Shading is as in Fig. 3.

\section{DISCUSSION}

The discussion of the data presented above is divided into two main topics. The first relates megacryst petrogenesis to that of the host alnoite, and the second discusses the origin of the host alnöite. The decoupled nature of the $\mathrm{Sm} / \mathrm{Nd}$ ("enriched") and ${ }^{143} \mathrm{Nd} /{ }^{144} \mathrm{Nd}$ ("depleted") isotope ratios from the host alnöite, indicates that it was derived from a source with a time-integrated LREE-depleted signature. Critical in our arguments, is the fact that metasomatism present in peridotite xenoliths has been demonstrated to be a consequence of alnöite magmatism (NEAL, 1988). No analyzed amphiboles contain an isotopic signature akin to the host alnöite. Rather, their signatures are within the range of the megacrysts. However, it is regarded as unlikely that the large degree of trace element fractionation required to generate the highly LREEenriched liquids from a LREE-depleted source can be achieved by conventional partial melting processes (KAY and GAST, 1973; BAILEY, 1982, 1984; FRASER et al., 1985). Furthermore, the range of $\mathrm{Sr}$ and $\mathrm{Nd}$ isotopic ratios exhibited by the megacrysts and host alnöite cannot be explained by conventional metasomatic or fractionation models. The isotopic disparity within the megacryst suite, and between the megacrysts and host alnöite, indicates a disequilibrium or open-system process.

In order to present our model of alnöite and megacryst petrogenesis, it is necessary to outline the assumptions and parameters used. In essence, we invoke diapiric upwelling deep within the mantle involving a zone refining process to generate a proto-alnöite magma. This is followed by a com-

Table 4: Representative garnet megacryst compositions.

\begin{tabular}{|c|c|c|c|c|c|c|}
\hline & CRN60 & CRN61 & CRN131 & CRN135 & CRN136 & CRN145 \\
\hline $\mathrm{SiO}_{2}$ & 41.8 & 41.1 & 41.2 & 41.5 & 40.9 & 41.5 \\
\hline $\mathrm{TiO}_{2}$ & 0.54 & 0.65 & 0.49 & 0.58 & 0.62 & 0.58 \\
\hline $\mathrm{Al}_{2} \mathrm{O}_{3}$ & 23.4 & 23.2 & 23.6 & 22.7 & 23.2 & 22.6 \\
\hline $\mathrm{Cr}_{2} \mathrm{O}_{3}$ & 0.19 & 0.09 & 0.11 & 0.21 & 0.04 & 0.17 \\
\hline$E \in O^{n}$ & 10.5 & 11.4 & 10.8 & 11.0 & 12.6 & 11.3 \\
\hline MnO & 0.27 & 0.32 & 0.30 & 0.28 & 0.34 & 0.33 \\
\hline $\mathrm{MgO}$ & 19.3 & 18.3 & 18.9 & 18.8 & 17.9 & 18.5 \\
\hline $\mathrm{CaO}$ & 4.52 & 4.63 & 4.60 & 4.74 & 4.28 & 4.69 \\
\hline TOTAL & 100.52 & 99.39 & 100.00 & 99.81 & 99.88 & 99.67 \\
\hline $\mathrm{Mg} \#$ & 76.7 & 74.1 & 75.8 & 75.4 & 71.7 & 74.4 \\
\hline Ca\# & 14.4 & 15.4 & 14.9 & 15.3 & 14.6 & 15.4 \\
\hline
\end{tabular}

Table 5: Reprcscntative ilmenite (discrete and Jaflellia megacryst compositions.

\begin{tabular}{|c|c|c|c|c|c|c|}
\hline & & DIS & CRETE I & 3ATTES & & \\
\hline & PHN3970 & PBNA101 & CRN6 3A & CRN63B & CRN63C & CRN6 3D \\
\hline $\mathrm{TiO}_{2}$ & 49.9 & 49.2 & 52.1 & 49.6 & 51.4 & 51.3 \\
\hline $\mathrm{A}_{2} \mathrm{O}_{3}$ & 0.83 & 0.63 & 0.17 & 0.60 & .28 & 0.23 \\
\hline $\mathrm{Cr}_{2} \mathrm{O}_{3}$ & 0.02 & 0.03 & nd & na & $n 1$ & $\mathrm{rad}$ \\
\hline $\mathrm{Fe}_{2} \mathrm{O}_{3}$ * & 11.0 & 10.5 & 4.64 & 8.23 & 4.86 & 6.43 \\
\hline Feo & 31.9 & 34.1 & 35.8 & 33.7 & $3+3$ & 35.5 \\
\hline MnO & 0.23 & 0.24 & 0.22 & 0.23 & 0.18 & 0.17 \\
\hline MgO & 7.13 & 5.23 & 6.67 & 6.56 & 6.64 & 6.40 \\
\hline $\mathrm{NiO}$ & 0.04 & 0.03 & 0.07 & 0.01 & 0.09 & nid \\
\hline TOTAL & 101.05 & 100.56 & 99.67 & 98.93 & 98.75 & 100.03 \\
\hline Mg\# & $2 B .5$ & 21.2 & 24.6 & 25.8 & 25.2 & 24.3 \\
\hline
\end{tabular}

nd = not detected; * = calculated by stochiometry.

CLINOPYROXENE-ILMBNTTE IUFBRCRONTHS

\begin{tabular}{lcccccc} 
& PHN3867 & PHN3868 & PHN3959 & PHN3960 & PHN3972 & PHN3973 \\
\hline $\mathrm{TiO}_{2}$ & 50.4 & 50.0 & 50.0 & 50.0 & 50.0 & 49.3 \\
$\mathrm{Al}_{2} \mathrm{O}_{3}$ & 0.39 & 0.95 & 0.86 & 0.99 & 1.07 & 0.93 \\
$\mathrm{Cr}_{2} \mathrm{O}_{3}$ & 0.02 & 0.01 & 0.02 & 0.02 & 0.02 & 0.02 \\
$\mathrm{Fe}_{2} \mathrm{O}_{3}$ & 10.9 & 10.6 & 10.5 & 10.4 & 10.3 & 12.2 \\
$\mathrm{FeO}$ & 31.7 & 32.0 & 31.3 & 30.5 & 31.1 & 29.3 \\
$\mathrm{MnO}$ & 0.29 & 0.21 & 0.24 & 0.20 & 0.23 & 0.23 \\
MgO & 7.36 & 7.07 & 7.49 & 7.96 & 7.58 & 8.30 \\
$\mathrm{NiO}$ & 0.03 & nd & 0.04 & 0.06 & 0.02 & 0.03 \\
TOTAL & $\mathbf{1 0 1 . 1 1}$ & $\mathbf{1 0 0 . 8 4}$ & $\mathbf{1 0 0 . 4 5}$ & $\mathbf{1 0 0 . 1 3}$ & $\mathbf{1 0 0 . 2 6}$ & $\mathbf{1 0 0 . 3 1}$ \\
Mg\# & 29.3 & 28.2 & 29.9 & 31.8 & 30.3 & 33.6 \\
\hline
\end{tabular}

nd $=$ not detected; $*$ = calculated by stochiometry.

bined assimilation and fractional crystallization (AFC) process at the base of the lithosphere, as the upward progress of the diapir is inhibited. The host alnöite is envisaged as a residual magma from these processes and does not require a metasomatized source.

\section{Megacryst petrogenesis}

By employing published crystal/liquid partition coefficients (Table 8) and assuming equilibrium, the REE composition of the liquid from which the megacrysts crystallized can be calculated. This allows the evolution of the proto-alnoite to be traced and demonstrates whether the megacrysts have crystallized from the host alnöite. Two independent partition

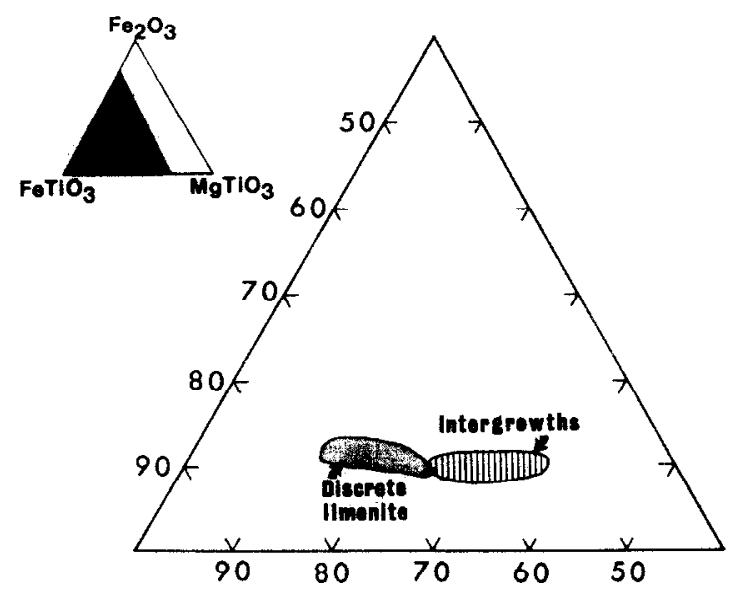

FIG. 6. Ilmenite megacryst compositions represented on a $\mathrm{Fe}_{2} \mathrm{O}_{3-}$ $\mathrm{FeTiO}_{3}-\mathrm{MgTiO}_{3}$ diagram. 


\begin{tabular}{|c|c|c|c|}
\hline & CRN123 & CRN124 & CRN127 \\
\hline $5 \mathrm{SO}_{2}$ & 37.5 & 38.3 & 37.8 \\
\hline $\mathrm{TO}_{2}$ & 6.50 & 6.47 & 6.52 \\
\hline $\mathrm{Al}_{2} \mathrm{O}_{3}$ & 14.2 & 15.0 & 14.7 \\
\hline $\mathrm{Cr}_{2} \mathrm{O}_{3}$ & nd & nd & nd \\
\hline $\mathrm{EeO}$ & 8.92 & 8.96 & 9.00 \\
\hline $\mathrm{MnO}$ & 0.05 & 0.05 & 0.04 \\
\hline $\mathrm{MgO}$ & 16.7 & 17.4 & 16.9 \\
\hline $\mathrm{CaO}$ & 0.06 & 0.12 & 0.05 \\
\hline $\mathrm{Na}_{2} \mathrm{O}$ & 0.39 & 0.75 & 0.60 \\
\hline$k_{2} \rho$ & 10.4 & 10.4 & 10.6 \\
\hline TOTAL & 94.72 & 97.45 & 96.22 \\
\hline $\mathrm{Mg}$ & 76.9 & 77.5 & 77.0 \\
\hline
\end{tabular}

coefficient determinations were used to check the consistency of this method for clinopyroxene and phlogopite megacrysts, and three for garnet megacrysts (Table 8).

Although not readily demonstrated in Fig. $8 \mathrm{a}$ and $\mathrm{b}$ because of the logarithmic scale, the augites have crystallized from an equilibrium liquid of generally flatter, more primitive REE profile $(\mathrm{La} / \mathrm{Yb}=15-18)$ than the subcalcic diopsides $(\mathrm{La} /$ $\mathrm{Yb}=17-26$ ). The liquid in equilibrium with the augites is akin to an alkali basalt $(\mathrm{La} / \mathrm{Yb} \cong 17)$, rather than the alnöite.

Three parent liquids for the garnet megacrysts have been calculated (Fig. 8c). These generally have a convex upwards rather than a LREE-enriched REE profile, probably because the LREE-depleted nature of garnet prohibits accurate $\mathrm{Kd}$ determinations for these elements. The results do demonstrate that the middle and heavy REE are subparallel to the alnöite.

The phlogopites have crystallized from a magma with a REE profile similar to that of the host alnöite (Fig. 8d). This supports the contention of DAwSON et al. (1978) that phlogopite crystallization occurred just prior to alnöite eruption.

The disparity in ${ }^{87} \mathrm{Sr} /{ }^{86} \mathrm{Sr}$ and ${ }^{143} \mathrm{Nd} /{ }^{144} \mathrm{Nd}$ ratios between the augite and subcalcic diopside megacrysts suggests they fractionated from two unrelated magmas. However, the increase in both $\mathrm{Sr}$ and $\mathrm{Nd}$ isotopic ratios could be generated by the progressive incorporation of an isotopically distinct component into the evolving proto-alnoite magma. The only suitable component able to do this (i.e., with high $\epsilon \mathrm{Nd}$ and ${ }^{87} \mathrm{Sr} /{ }^{86} \mathrm{Sr}$ ) is seawater-altered basalt (SWAB) (or derivatives thereof) which is returned to the Earth's interior via subduction. Indeed, direct evidence for the presence of subducted oceanic crust beneath the OJP has been reported by NEAL and TAYLOR (1989). The most simplistic scenario would be one of bulk mixing between proto-alnöite and SWAB magmas. However, we consider the most geologically feasible process to be melting of the SWAB component by the protoalnöite magma. Therefore, we envisage an AFC process beneath the OJP (DEPAOLO, 1981), whereby the proto-alnöite magma (alkali basalt) assimilates seawater-altered basalt while fractionating the observed megacryst assemblage, as it impinges upon the rigid lithosphere.

The isotope results suggest the augite megacrysts crystallized first (flattest equilibrium liquid REE profile; least radiogenic $\mathrm{Sr}$ and Nd isotopes) followed by the subcalcic diop- sides. As the equilibrium liquid REE profiles become steeper, the $\mathrm{Sr}$ and Nd isotopes become more radiogenic. This indicates a greater influence of seawater-altered subducted oceanic crust upon the proto-alnöite, as it evolves by megacryst fractionation. The calculated equilibrium liquid REE profiles from the garnet megacrysts preclude any definite conclusions, although the isotope data suggest they probably span the range of clinopyroxene crystallization. Phlogopite megacrysts were the last to crystallize, just prior to alnöite eruption, as indicated by an equilibrium liquid similar to alnöite and $\mathrm{Sr}$ isotopes approaching alnöite ratios.

The $r$ value was determined by consideration of the basaltbasalt interaction and was originally estimated as 0.3 . This value was adjusted slightly to 0.36 in order to encompass all data (Fig. 9). This value is in agreement with the modeling of KELEMEN (1986) in which mafic magma interacts with an essentially ultramafic wallrock component. The proportions of the megacryst phases fractionated are: augite $30 \%$, bronzite $5 \%$, subcalcic diopside $24.5 \%$, garnet $27 \%$, ilmenite $0.5 \%$, and phlogopite $13 \%$. Note that the alnöite is produced after $60 \%$ fractional crystallization in this model. As we envisage this process to occur at the base of the lithosphere, pressure constraints will negate olivine fractionation, resulting in the crystallization of orthopyroxene (bronzite) as the high-Mg phase (e.g., O'HARA and YODER, 1967; THOMPSON, 1974). The decrease in the jadeite component from the augites to the subcalcic diopsides is also a function of the relatively high pressure of megacryst fractionation. Although at lower pressures the crystal/liquid partition coefficient for $\mathrm{Na}$ in clinopyroxene is $\ll 1$, at higher pressures this increases dramatically due to the stability of jadeite (e.g., YODER and TILLEY, 1962; KUSHIRO, 1979). Therefore, a decrease in jadeite component in continuously fractionated clinopyroxenes is expected from a basaltic magma crystallizing at relatively high pressures (20$30 \mathrm{Kbar})$. A decrease in pressure during crystallization will

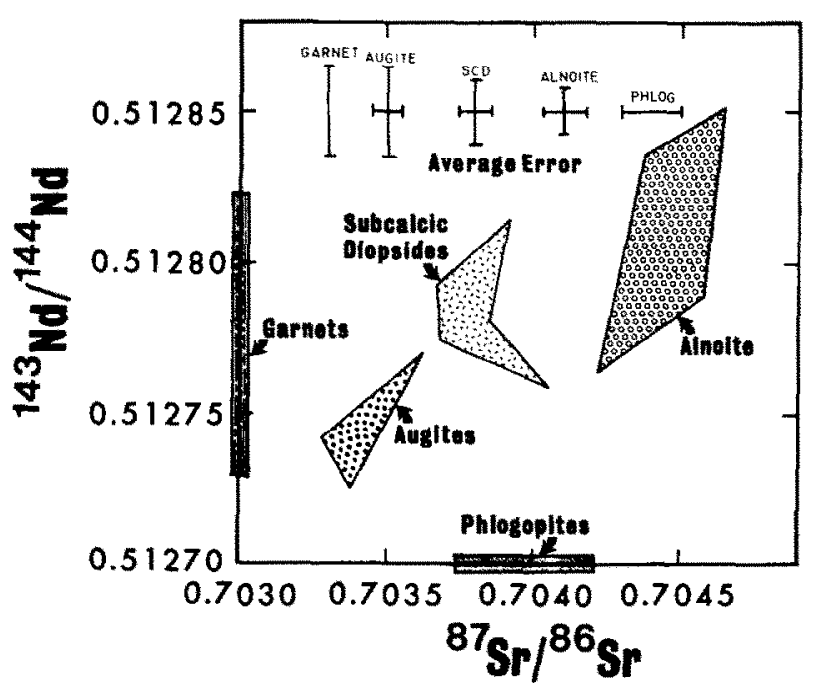

FIG. 7. ${ }^{143} \mathrm{Nd} /{ }^{144} \mathrm{Nd} v s .{ }^{87} \mathrm{Sr} /{ }^{86} \mathrm{Sr}$ diagram for the augite, subcalcic diopside, garnet, and phlogopite megacrysts, and the host alnöite. Note that the garnet megacryst have been analyzed only for Nd isotopes and have been plotted on the ${ }^{143} \mathrm{Nd} / 144 \mathrm{Nd}$ axis. Similarly, the phlogopite megacrysts have only been analyzed for $\mathrm{Sr}$ isotopes and have been plotted on the ${ }^{87} \mathrm{Sr} /^{86} \mathrm{Sr}$ axis. 


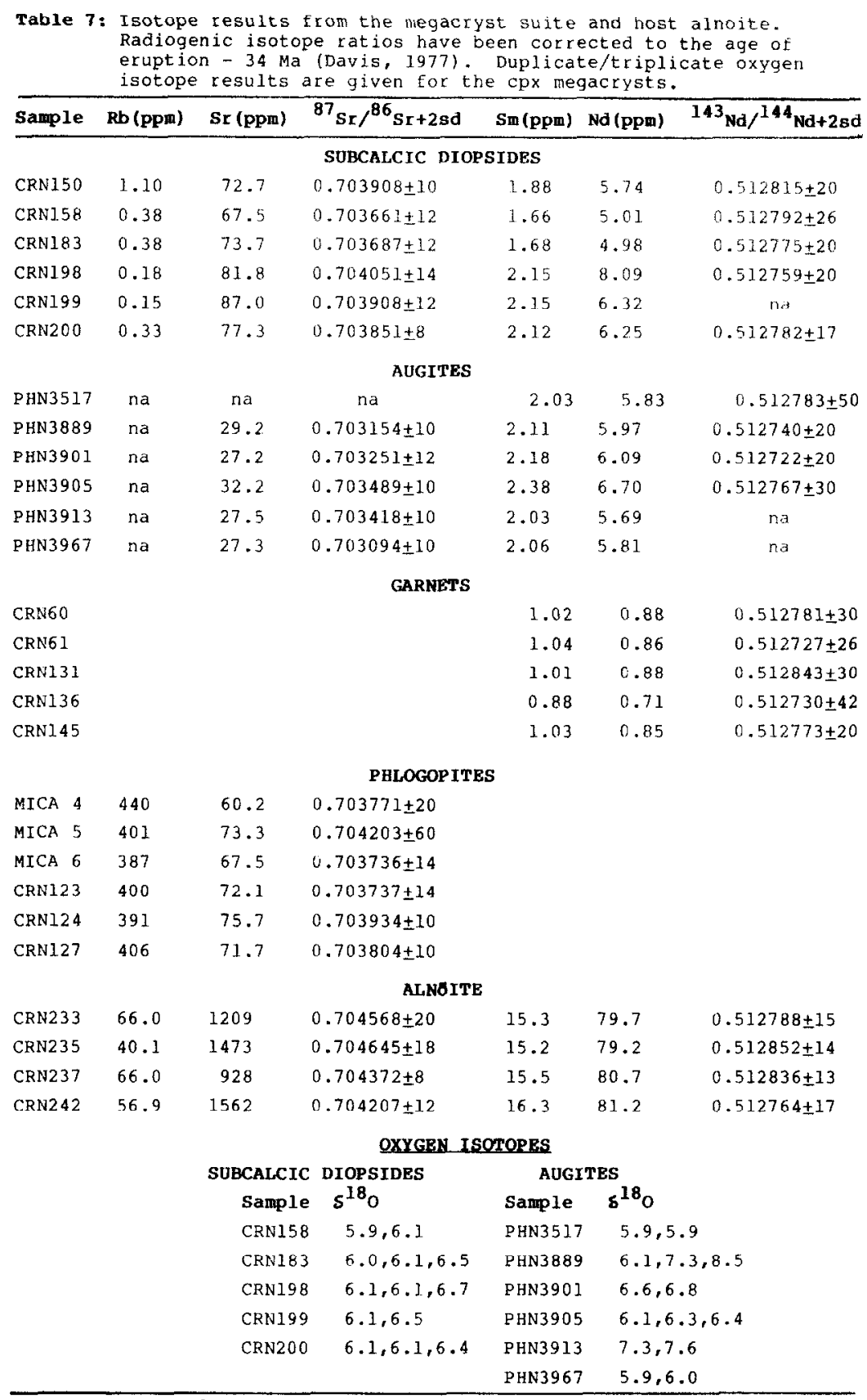

na = not analyzed.

also decrease the $\mathrm{Na}$ content of the clinopyroxenes, as the stability field of jadeite is diminished.

Evidence that the augites crystallized before the subcalcic diopsides is seen from the $\mathrm{Sr}$ abundances in these megacrysts. No megacryst phase present in the Malaitan alnöite has a crystal/liquid partition coefficient of $>1$ for $\mathrm{Sr}$. Therefore, $\mathrm{Sr}$ will increase in the residual liquid, if the mcgacrysts fractionated from a single magma. As augite and diopside have similar crystal/liquid partition coefficients for strontium (e.g. PHILPOTTS and SCHNETZLER, 1970; ARTH and HANSON, 1975), the change in Sr contents of the clinopyroxene megacrysts is directly related to the $\mathrm{Sr}$ content of the liquid from which they crystallized (Fig. 10a). Using this rationale, the subcalcic diopsides (67-87 ppm Sr) crystallized after the augites (27-32 ppm Sr). Sr abundance correlates also with $\mathrm{Mg \#}$ of these megacrysts, indicating as $\mathrm{Sr}$ abundance increases, $\mathrm{Mg}$ \# increases (Fig. 10b). Reversed fractionation schemes (i.e., increases in $\mathrm{Mg \#}$ as crystallization proceeds) have been noted on a smaller scale by WEIBLEN et al. (1981) in alkali basalts from Ross Island, Antarctica, where clinopyroxenes exhibit an increase in $\mathrm{Mg}$ \# from core to rim. A similar situation has also been reported by BROOKS and RUCKLIDGE (1973) in alkali basalts from Greenland. This reversed fractionation scheme has been attributed to oxidation of the magma during 


\begin{tabular}{|c|c|c|c|c|c|c|c|c|}
\hline & Augite 1 & Augite & Augite ${ }^{3}$ & $\operatorname{sCn}^{1}$ & $\mathrm{scd}^{2}$ & $\mathrm{sCD}^{3}$ & ofx ${ }^{1}$ & opx ${ }^{8}$ \\
\hline $\mathrm{Rb}$ & 0.031 & ---- & ---- & 0.015 & $--m$ & $\cdots--$ & 0.022 & $-\cdots$ \\
\hline$s r$ & 0.12 & ---- & --- & 0.12 & $-\cdots$ & $-\cdots$ & 0.017 & $--\infty$ \\
\hline $\mathrm{Ba}$ & 0.026 & $-m-m$ & --- & 0.013 & $--m$ & --- & 0.013 & $--\infty$ \\
\hline $\mathrm{Ce}$ & 0.15 & 0.077 & 0.098 & 0.07 & 0.043 & 0.098 & $-\cdots$ & 0,003 \\
\hline Na & 0.31 & 0.174 & 0.21 & 0.12 & 0.065 & 0.21 & $--\infty$ & 0.007 \\
\hline $5 \mathrm{~m}$ & 0.50 & 0.26 & 0.26 & 0.18 & 0.09 & 0.26 & ---- & 0,01 \\
\hline $\mathrm{Eu}$ & 0.51 & 0.273 & 0.31 & 0.18 & 0.091 & 0.31 & $--\cdots$ & 0.013 \\
\hline $\mathrm{Ga}$ & 0.61 & 0.325 & 0.30 & 0.19 & 0.095 & 0.30 & --- & 0.016 \\
\hline DY & 0.68 & 0.351 & 0.33 & 0.21 & 0.105 & 0.33 & $\cdots$ & 0.022 \\
\hline $\mathbf{E} \mathbf{r}$ & 0.65 & 0.33 & 0.30 & 0.17 & 0.107 & 0.30 & $-\cdots$ & 0.03 \\
\hline \multirow[t]{2}{*}{$Y b$} & 0.62 & 0.294 & 0.28 & 0.16 & 0.092 & 0.28 & $-\cdots$ & 0.049 \\
\hline & Garnet $^{1}$ & Garnet & Gaxnet 5 & Phlog 2 & Phlog 6 & Phlog 7 & $\operatorname{zircon} 7$ & I Imenite \\
\hline$R b$ & 0.042 & ---- & --- & 3.06 & 3.06 & $-\cdots$ & 0.25 & $(0.01)$ \\
\hline sr & 0.012 & ---- & $-n-\ldots$ & 0.081 & 0.081 & $-\cdots-$ & ---- & 0.005 \\
\hline $\mathrm{Ba}$ & 0.023 & ---- & ---- & 1.09 & 1.09 & $-\infty-\infty$ & ---- & 0.005 \\
\hline$c e$ & 0.028 & 0.007 & 0.021 & 0.034 & 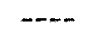 & 0.014 & 0.13 & 0.006 \\
\hline Nd & 0.068 & 0.026 & 0.087 & 0.032 & $-\cdots$ & 0.017 & $(0.25)$ & 0.008 \\
\hline $\mathrm{sm}$ & 0.29 & 0.131 & 0.217 & 0.031 & --- & 0.015 & 0.38 & 0.01 \\
\hline Eu & 0.49 & 0.273 & 0.32 & 0.03 & --- & 0.029 & 1.26 & 0.007 \\
\hline $\mathrm{Ga}$ & 0.97 & 0.68 & 0.498 & 0.03 & ---- & 0.014 & $(2.5)$ & 0.014 \\
\hline DY & 3.17 & 1.94 & 1.06 & 0.03 & ---- & 0.019 & (11) & 0.025 \\
\hline Er & 6.56 & 4.7 & 2.0 & 0.034 & ---- & $(0.025)$ & $(50)$ & 0.043 \\
\hline$Y \mathrm{~b}$ & 11.5 & 8.0 & 4.03 & 0.042 & $--m$ & 0.03 & 138 & 0.075 \\
\hline
\end{tabular}

Brackets indicate estimated partition coefficient.

1 Arth and Hanson (1975): 2 = Schnetzler and Philpotts (1970);

$3=$ Grutzeck et al. (1974); $4=$ Irving and Frey (1978); $5=$ Shimuzu

and Kushiro (1975); $6=$ philpotts and schnetzler $(1970) ; 7=$ Truing

and Frey $(1984) ; 8=$ Hanson $(1980) ; 9=$ Binder $(1982)$.

ascent or to complicated local reactions between the pyroxene and the magma. It is unclear which is applicable to the Malaitan megacrysts.

Oxygen isotopes have been measured only from the clinopyroxene megacrysts (Table 7) and have been plotted against strontium (Fig. 11). The oxygen isotopes should also reflect the nature of the inferred assimilated seawater-altered basaltic component. Seawater alteration of oceanic crust results in both enrichments and depletions in $\delta^{18} \mathrm{O}$ relative to a mantle average of $\cong+5.7 \%$ (e.g., GREGORY and TAYLOR, 1981). This depends on the temperature at which exchange with seawater occurs, and also the mineralogy of the oceanic crust (altered/unaltered). High temperatures cause depletions and low temperatures cause enrichments in $\delta^{18} \mathrm{O}$ relative to the average mantle value.

The oxygen data may be interpreted in two ways: (1) the subcalcic diopsides $\left(\delta^{18} \mathrm{O}=+5.9-6.1 \%\right)$ crystallized first and the proto-alnöite assimilated a portion of subducted oceanic crust which had undergone very limited low-temperature seawater alteration; or (2) the augites $\left(\delta^{18} \mathrm{O}=+5.9\right.$ to $\left.+7.3 \%\right)$ crystallized first and the proto-alnoite assimilated a portion of subducted oceanic crust which had undergone higher temperature seawater alteration. It is possible that this range in augite megacryst $\delta^{18} \mathrm{O}$ is due to submicroscopic grain boundary contamination, but with the stringent handpicking and leaching procedures undertaken (see Appendix), we consider this to be unlikely.
We consider that the range in oxygen isotopes is caused by the second hypothesis, especially as the first hypothesis is in contradiction to the $\mathrm{Sr}$ isotope data (see above). If the pillow basalt portion of the oceanic crust was assimilated, ${ }^{87} \mathrm{Sr} /{ }^{86} \mathrm{Sr}$ ratios would be expected to increase with $\delta^{18} \mathrm{O}$, but this is not the case. If the proto-alnoite assimilated subducted oceanic crust, it is likely to have been the dike portion, as this can contain depleted (relative to mantle values) $\delta^{18} \mathrm{O}$ (AIt et al., 1986, MUEHLENBACHS, 1986) and also high enough ${ }^{87} \mathrm{Sr} /{ }^{86} \mathrm{Sr}$ (MCCULLOCH et al., 1981) to facilitate the range in isotopic ratios observed at Malaita.

\section{Proto-alnöite and host alnöite petrogenesis}

Generation of the magma or proto-alnöite from which the megacrysts crystallized is difficult to model. It has become widely accepted that metasomatically enriched source region is required to generate kimberlite and alkali basalt (e.g., KAY and GAST, 1973; BAILEY, 1982, 1984). However, the ${ }^{143} \mathrm{Nd} /$ ${ }^{144} \mathrm{Nd}$ ratios of the augite megacrysts (first crystallized phase) indicate that the proto-alnöite source exhibits a time-integrated LREE-depleted signature. Also, it has been demonstrated that metasomatism of peridotite xenoliths is a consequence of alnöite magmatism (NEAL, 1988), and the mechanism of metasomatism just prior to eruption is somewhat fortuitous. Therefore, our model for alnöite generation, although somewhat speculative, is intended as a feasible al- 

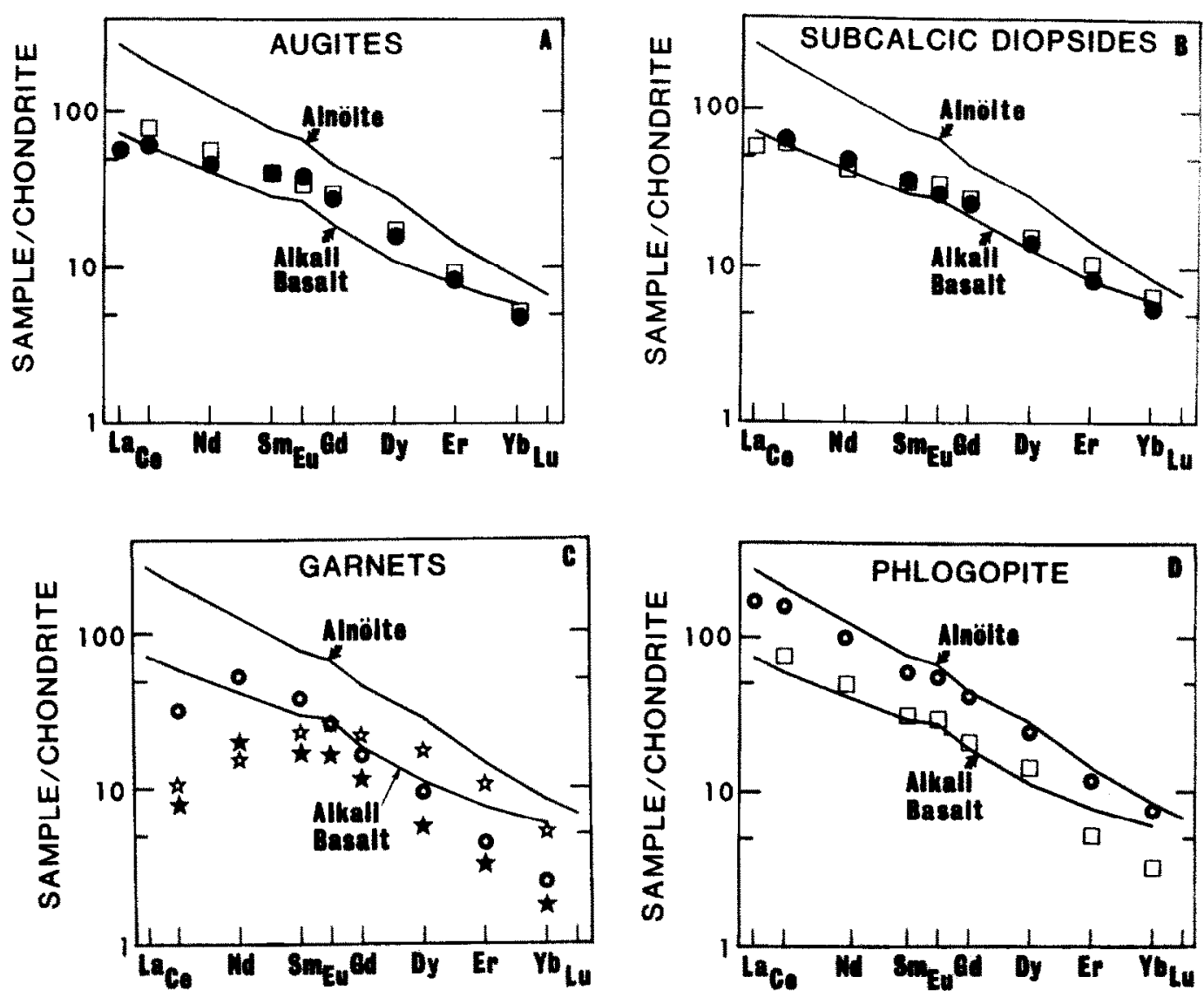

FIG. 8. Calculated "equilibrium liquids" for (A) the augite megacrysts; (B) the subcalcic diopside megacrysts; (C) the garnet megacrysts; and (D) a phlogopite megacryst. Filled circles = GRUTZECK et al. (1974); open circles = SCHNETZLER and PHILPOTTS (1970); circled stars = IR VING and FREY (1984); open stars = SHIMUZU and KUSHIRO (1975); filled stars = ARTH and HANSON (1975). The average REE profile of the host alnoite and an alkali basalt (FREY et al, 1978) are shown for reference.

ternative to the idea of metasomatic enrichment, in that an unmetasomatized LREE-depleted source is envisaged. However, the $\mathrm{Sm} / \mathrm{Nd}$ ratio is not as depleted as in MORB source, as the ${ }^{143} \mathrm{Nd} /{ }^{144} \mathrm{Nd}$ ratio of the proto-alnöite is only slightly elevated relative to bulk earth.

We invoke the process of zone refining (HARRIS, 1957, 1974; HARRIS and MIDDLEMOST, 1969; HANSON, 1980) to generate the proto-alnöite from a LREE-depleted mantle peridotite. This source composition (Fig. 12; Table 9) was compiled from garnet peridotite compositions reported by SHIMUZU (1975), EHRENBERG (1982), and JONES (1984). Melt is produced by diapiric upwelling within the asthenosphere (GREEN and GUEGUEN, 1974) initiated by a thermal density perturbation. As the diapir rises it undergoes partial melting due to pressure-release, and this melt will congregate at the top of the diapir. Using the zone refining formula of HARRIS (1974), the REE abundances have been calculated in a diapiric melt which has passed through 200 times its own volume. The maximum depth for the initiation of diapiric upwelling is $1000 \mathrm{~km}$; as HARTE and GURNEY (1981) have suggested the megacryst magma chamber is $<5 \mathrm{~km}$ in extent. Furthermore, HARTE and GURNEY (1981) conclude that megacrysts are crystallized under essentially isobaric conditions, consis- tent with impingement of the diapir upon the rigid lithosphere. The crystallization of the proto-alnoite will be accompanied by assimilation of subducted oceanic crust (modeled after DEPAOLO, 1981, Eqn. 6a). The seawater-altered MORB composition has been compiled from LUDDEN and THOMPSON (1979), HUMPHRIS and THOMPSON (1978), and STAUDIGEL et al. (1981), and is presented in Table 9.

The zone refining process produces a magma analogous to an alkali basalt, which is expected from equilibrium liquid REE profiles from augite megacrysts. Note that the $\mathrm{La} / \mathrm{Yb}$ ratio of the alnöite cannot be generated by zone refining alone. The melt produced is LREE-enriched, but will still maintain depleted Nd isotopic signature of the source region as the speed of this process does not allow sufficient time for ${ }^{143} \mathrm{Nd}$ / ${ }^{144} \mathrm{Nd}$ to reflect the new $\mathrm{Sm} / \mathrm{Nd}$ ratio. The diapiric rise is either halted or drastically slowed with impingement upon the rigid lithosphere. Here the melt produced begins to crystallize and fractionate the megacryst suite. Note that in Fig. 12 and Table 9 the REE profile for the proto-alnoite produced by zone refining is in good agreement with that predicted from clinopyroxene megacryst equilibrium liquids (i.e., an alkali basalt). The proportions of megacrysts fractionated are the same as in the isotope modeling, except zircon has been 


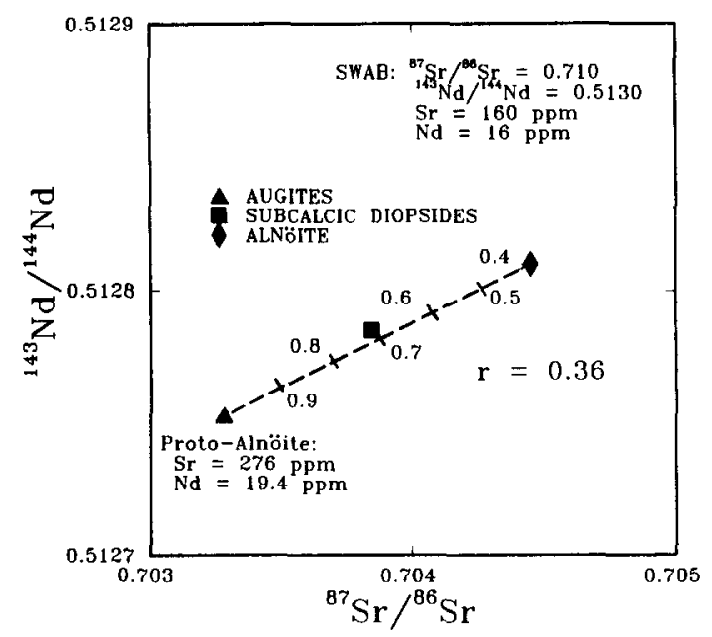

FIG. 9. $\mathrm{A}^{143} \mathrm{Nd} /{ }^{144} \mathrm{Nd} v s .{ }^{87} \mathrm{Sr} /{ }^{86} \mathrm{Sr}$ diagram illustrating a calculated AFC path between a proto-alnöite (represented by the augite megacrysts) and Seawater-Altered Basalt (SWAB). SWAB data from MCCULLOCH et al. (1981). Average clinopyroxene megacryst and alnöite compositions are plotted.

included $(0.1 \%)$ and phlogopite is reduced from 13 to $12.9 \%$. The $F$ value used in the assimilation fractional crystallization calculation is $0.4(60 \%$ crystallization of the proto-alnöite liquid) and the $r$ value is 0.36 (also consistent with the isotope modeling). The residual liquid calculated after zone refining, megacryst fractionation, and crustal assimilation compares well with the measured Malaitan alnöite.

Although the oxygen data are within the present mantle $\delta^{18} \mathrm{O}$ range (e.g., KYSER et al., 1981, 1982; GRAHAM and HARMON, 1983), the results are ambiguous (see above). The

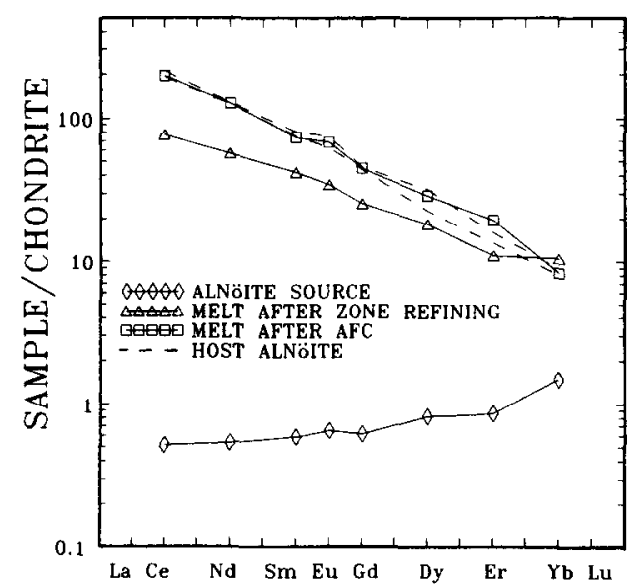

FIG. 10. A chondrite-mormalized trace element plot of the REE, $\mathrm{Rb}, \mathrm{Sr}$, and $\mathrm{Ba}$. Compositions illustrated are a depleted source (calculated from SHIMUZU, 1975, and EHRENBERG, 1982), the magma after zone refining, and the magma after AFC. The range in the host alnöite is shown for reference. The source mineralogy is taken as: Olivine $79.5 \%$; Orthopyroxene $13.5 \%$; Garnet $3.5 \%$; Diopside $3.5 \%$. The megacrysts are fractionated in the proportions: Augite $30 \%$; garnet $27 \%$; subcalcic diopside $24.5 \%$; phlogopite $12.9 \%$; bronzite $5 \%$; ilmenite $0.5 \%$; zircon $0.1 \%$. Partition coefficients used are as in Fig. 8 and also from IRVING and FREY (1978). $F=0.4, r=0.36$.

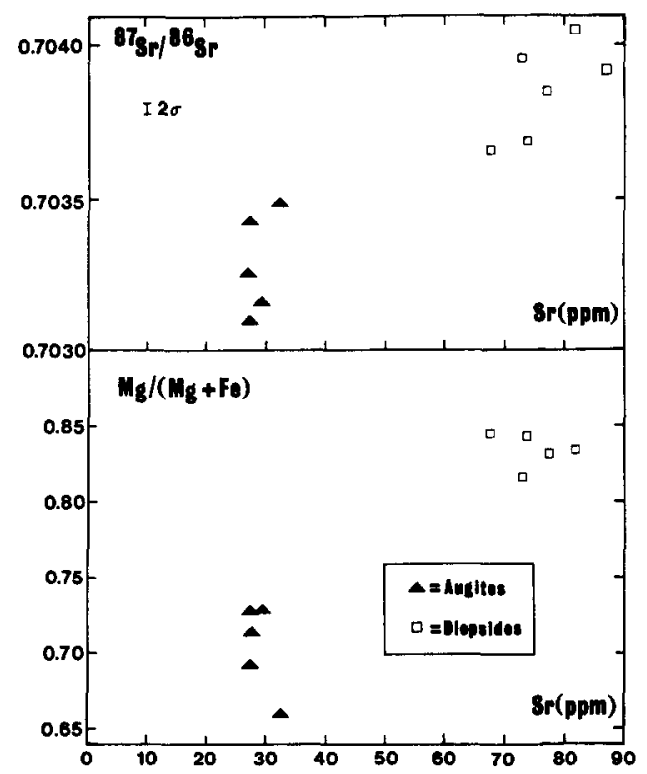

FIG. 11. A plot of $\mathrm{Sr}$ abundance $v s .{ }^{87} \mathrm{Sr} /{ }^{86} \mathrm{Sr}$ and $\mathrm{Mg} \#$ of the augite and subcalcic diopside megacrysts.

significance of these oxygen isotope data may be emphasized by comparison with previous oxygen isotope studies of mantle-derived magmas and xenoliths. In one such study, KYSER et al. (1982) noted that alkali basalts have $\delta^{18} \mathrm{O}$ ranging from +6 to $+8 \%$, higher than that for tholeiitic basalts $(\cong 5.7 \%$ ). These authors concluded that such elevated $\delta^{18} \mathrm{O}$ compositions are a product of a source composition which has already experienced depletion(s) by partial melting. As the inferred proto-alnöite is an alkali basalt derived from a depleted source, it is feasible that the $\delta^{18} \mathrm{O}$ will be $7-7.5 \%$, and will be reflected in the augite megacrysts. Upon assimilation of

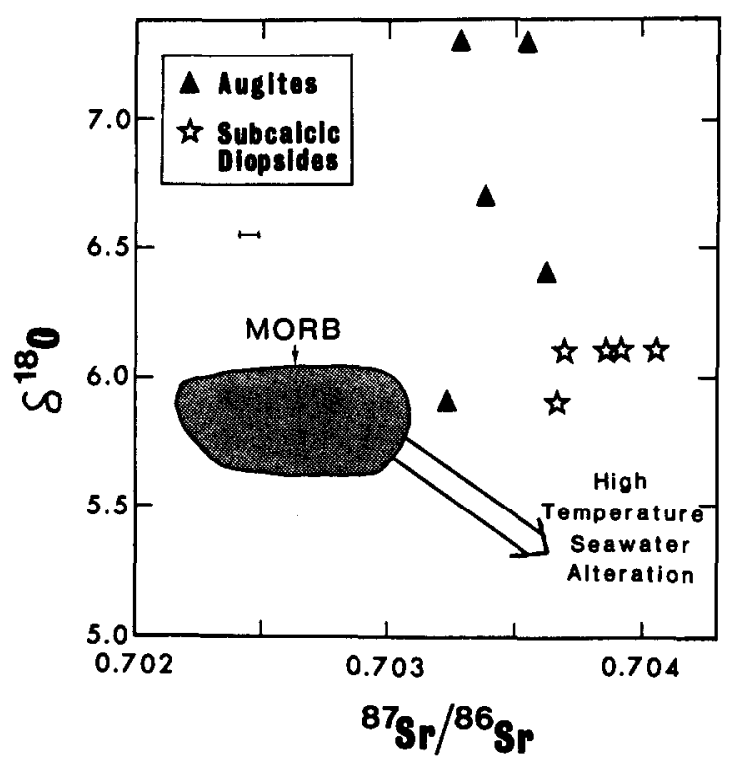

FIG. 12. A plot of $\delta^{18} \mathrm{O} v s .{ }^{87} \mathrm{Sr} /{ }^{86} \mathrm{Sr}$ illustrating the effect of SWAB assimilation on the clinopyroxene megacrysts. 


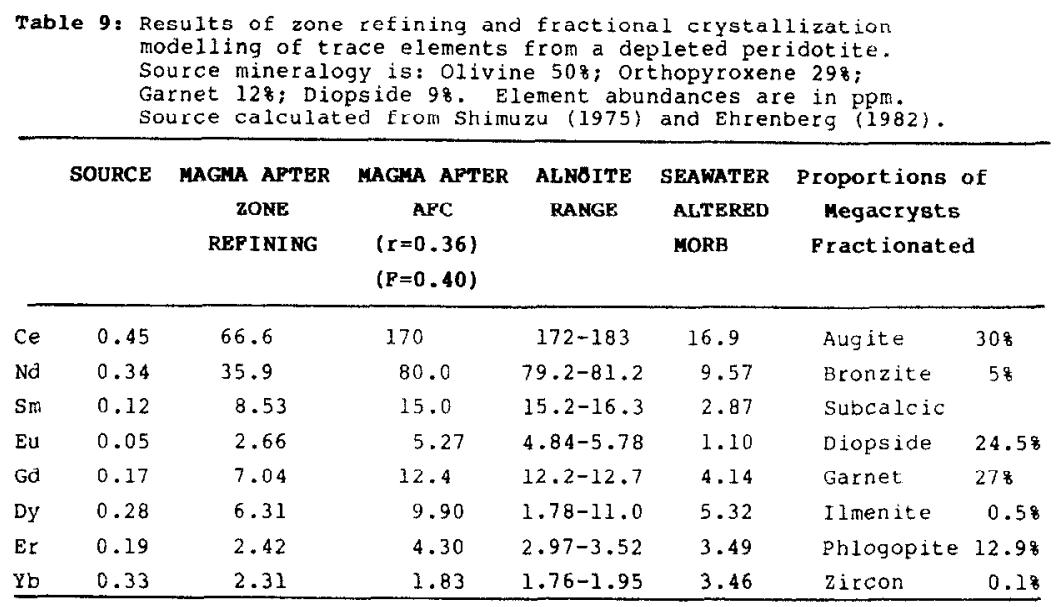

seawater-altered basalt, the $\delta^{18} \mathrm{O}$ of the magma is decreased, witnessed by the oxygen isotope compositions of the augite and subcalcic diopside megacrysts. As the augites are considered to have crystallized first, the range in $\delta^{18} \mathrm{O}$ values may reflect the initial effect of seawater-altered basalt on the protoalnöite magma. The more constricted $\delta^{18} \mathrm{O}$ values of the later crystallized subcalcic diopsides probably indicate a more homogeneous magma during the later stages of evolution.

Two previous isotopic studies of the Malaitan alnöite and its entrained xenoliths have been conducted (BIELSKI-ZYSKIND et al., 1984; RUBENSTONE and ZINDLER, 1989). RUBENSTONE and ZINDLER (1989) suggested either sequential or singular enrichment of the mantle beneath the OJP by a LREE-enriched component. NEAL (1988) demonstrated that this mantle enrichment was a consequence of alnöite magmatism. BIELSKI-ZYSKIND et al. (1984) concluded that the source reservoir for the Malaitan alnöite consisted of either $99 \%$ depleted mantle and $1 \%$ of enriched continental material, or small proportions of deeply subducted young crustal material and depleted mantle. Our model also requires a crustal component, but differs from BIELSKI-ZYSKIND et al. (1984) in that it is seawater-altered MORB rather than of continental origin. With our increased database, more definitive conclusions may be drawn as to the petrogenesis of the Malaitan alnöite and its entrained xenoliths.

The model presented in this study illustrates that the isotopic and REE data from the alnöite can be generated by zone refining of a LREE-depleted source, followed by an AFC process at the base of the lithosphere. We recognize that all trace elements have not been included in this model, due to the lack of data for these elements in the garnet peridotite source and the assumed proto-alnöite composition (alkali basalt). In order to thoroughly test the proposed model, these will have to be accounted for when the data has been collected. However, the data outlined above can be adequately explained by this zone refining-AFC scheme, and presents a viable alternative to the metasomatic models. The salient features of our proposed model are summarized below.

\section{Model for alnöite petrogenesis (Fig. 13)}

1. Initiation of diapiric upwelling deep within a LREEdepleted asthenosphere.
2. Melt is produced by pressure release and undergoes zone refining as it rises $(\mathrm{N}=200)$. This produces a magma which is alkali basalt in character.

3. When the diapir impinges on the rigid lithosphere, its progress is halted and it begins to cool. At this point fractionation of the megacryst suite occurs.

4. A subducted derivative of oceanic crust underplating the OJP is assimilated by the proto-alnöite magma during megacryst fractionation (an AFC process).

5. The alnöite is therefore a product of zone refining, fractional crystallization, and crustal assimilation.

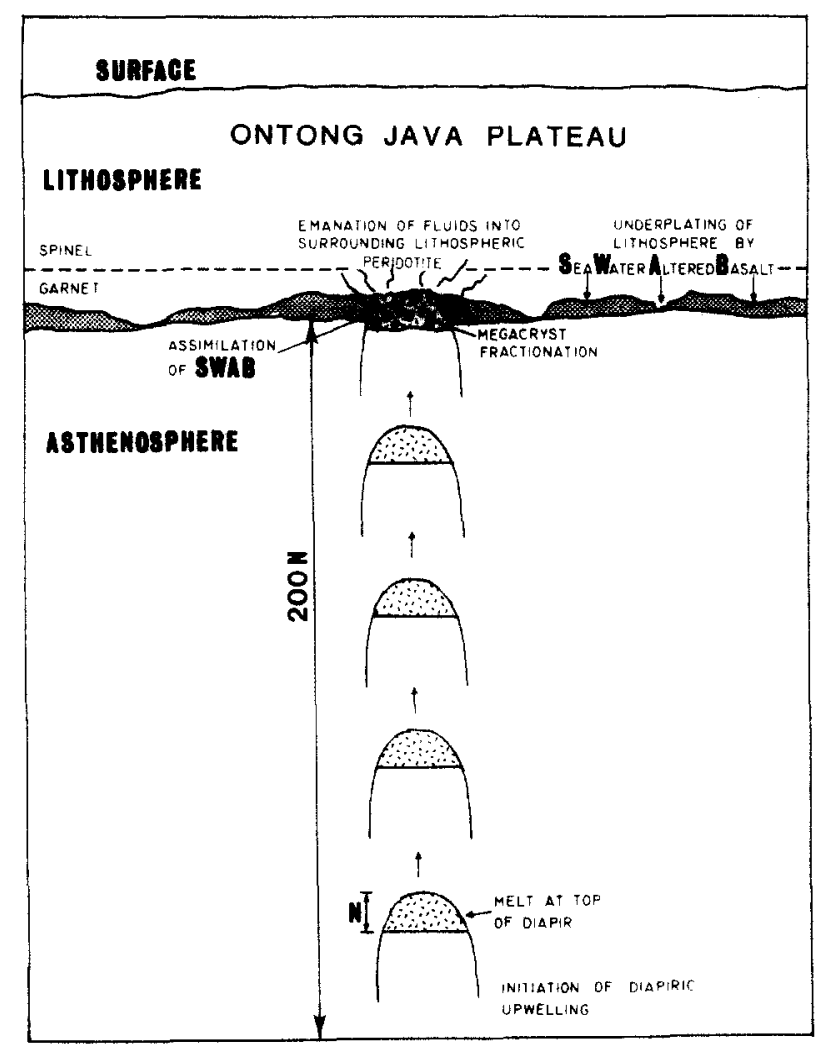

FIG. 13. lllustration of the envisaged processes involved in the petrogenesis of the Malaitan alnöite. 
6. Ascent to the surface is controlled by pressure-induced fracture propagation and pre-existing fracture zones (ANDERSON, 1979; SPERA, 1984).

\section{SUMMARY}

Major element trends from the Malaitan megacryst suite indicate fractionation from a single, evolving magma. The host alnoite is the end-product of this process. This hypothesis is supported by REE modeling, where equilibrium liquids calculated for the various megacryst phases demonstrate a steepening of REE profile as fractionation proceeds. Isotopic disparity between the megacrysts and the host alnöite, and within the megacryst suite, is facilitated by an assimilation and fractional crystallization process between a proto-alnöite magma and a subducted derivative of oceanic crust. REE modeling indicates the proto-alnöite magma was alkali basalt in character. Modeling of this AFC process indicates that the alnöite is produced after $60 \%$ crystallization of the protoalnöite magma. The $\mathrm{Sr}$ and $\mathrm{Nd}$ isotope (and elemental abundances) coupled with REE data indicate the augite megacrysts fractionated before the subcalcic diopsides. This requires that the proto-alnöite magma becomes depleted in $\mathrm{Ca}$ and enriched in $\mathrm{Mg}$. The trace element and isotope modeling give the same results, namely the alnöite is produced after $60 \%$ crystallization of the proto-alnöite magma (fractionating megacryst proportions: augite $30 \%$, bronzite $5 \%$, subcalcic diopside $24.5 \%$, garnet $27 \%$, ilmenite $0.5 \%$, phlogopite $12.9 \%$, and $0.1 \%$ zircon), while assimilating $21.6 \%$ of subducted oceanic crust $(r=0.36)$.

From the above discussion, it is apparent that the alnoite is not a primary mantle melt. It is derived from a LREEdepleted source, on the basis of Nd isotopes, and no direct evidence of source metasomatism is found. A zone refining process is used to model the REE from a LREE-depleted asthenospheric source to produce the alkali basaltic protoalnöite composition. After megacryst fractionation, the alnöite which is seen at the surface is produced.

The conclusions drawn from this study indicate that (a) a metasomatized source is not essential for alnöite generation; (b) megacrysts have a relationship, albeit indirect, with the host magma; (c) careful examination is required in order to determine whether these mantle-derived magmas are primary melts; and (d) crustal interaction may be significant in the evolution of such melts. Whether our model is applicable to kimberlites and alkali basalts requires that each case be studied individually. Although the concept of a metasomatized source for mantle-derived magmas cannot be unequivocally disproven, the argument for an unmetasomatized source and megacryst fractionation from a proto-alnöite magma is certainly strong for the petrogenesis of the Malaitan alnöite.

Acknowledgements-Many thanks go to J. Borthwick for assistance in, and R. S. Harmon for permission to use, the oxygen isotope analytical facilities at Southern Methodist University, Dallas. Actual analyses were performed hy JPD. Pete Nixon provided invaluable help both with samples and constructive criticisms. This paper has greatly benefited from the thoughtful reviews of John Shervais, Robert Cullers, Roger Mitchell, and Jan Hertogen. Larry Taylor at the University of Tennessee is acknowledged for scientific and financial contributions. We are also indebted to the staff of the Isotope Lab at the
University of Leeds, and to Richard Jones, Steve Flint, Gareth Davies. and Steve Caunt for critical appraisals. Special thanks is extended to the government and people of the Solomon Islands, without whose help and cooperation this project would not have been possible. This research was funded by a grant from N.E.R.C.

Editorial handling: J. IIertogen .

\section{REFERENCES}

AKELLA J. (1976) Garnet pyroxene equilibria in the system $\mathrm{CaSiO}_{3-}$ $\mathrm{MgSiO}_{3}-\mathrm{Al}_{2} \mathrm{O}_{3}$ and in a natural mineral mixture. Amer. Mineral. 61, 589-598.

ALLEN J. B. and DEANS T. (1965) Ultrabasic eruptives with alnoitickimberlitic affinities from Malaita, Solomon Islands. Mineral. Mag. 34, 16-34.

Alt J. C., MuehlenbaChs K. and Honnorez J. (1986) An oxygen isotopic profile through the upper kilometer of the oceanic crust, DSDP hole 504B. Earth Planet. Sci. Lett. 80, 217-229.

ANDERSON O. L. (1979) The role of fracture dynamics in kimberlite pipe formation. In Kimberlites, Diatremes, and Diamonds: Their Geology, Petrology, and Geochemistry, (eds. F. R. BoYD and H. O. A. MEYER); Proc. 2nd Intl. Kimberlite Conf., pp. 344-353. American Geophysical Union.

ARTH J. G. and HANSON G. N. (1975) Geochemistry and origin of the early Pre-Cambrian crust of NE Minnesota. Geochim. Cosmochim. Acta 39, 325-362.

BAILEY D. K. (1982) Mantle metasomatism-continuing change within the Earth. Nature 296, 525-530.

BAILEY D. K. (1984) Kimberlite: "The Mantle Sample" formed by ultrametasomatism. In Kimberlites I: Kimberlites and Related Rocks, (ed. J. KORNPROBST); Proc. 3rd Intl. Kimberlite Conf., pp. 323-334. Elsevier.

Basaltic VolCanism Study Project (1981) Basaltic Volcanism on the Terrestrial Planets. Pergamon Press, 1286p.

BIELSKI-ZYSKIND M., WASSERBURG G. J. and NIXON P. H. (1984) $\mathrm{Sm}-\mathrm{Nd}$ and $\mathrm{Rb}-\mathrm{Sr}$ systematics in volcanics and ultramafic xenoliths from Malaita, Solomon Islands, and the nature of the Ontong Java Plateau. J. Geophys. Res. 89, 2415-2424.

BINDER A. B. (1982) The mare basalt magma source region and mare basalt magma genesis. J. Geophys. Res. 87, A37-A53.

BORTHWICK J. and HARMON R. S. (1982) A note regarding $\mathrm{ClF}_{3}$ as an alternative for $\mathrm{BrF}_{5}$ for oxygen isotope analysis. Geochim. Cosmochim. Acta 46, 1665-1668.

BOYD F. R. and NIXON P. H. (1973) Origin of the ilmenite-silicate nodules in kimberlites from Lesotho and southern Africa. In Lesotho Kimberlites (ed. P. H. NIXON), pp. 254-268. Lesotho National Dev. Corp.

BoyD F. R. and NIXON P. H. (1975) Origins of ultramafic nodules from sole kimberlites of northern Lesotho and Monastery Mine, South Africa. Phys. Chem. Earth 9, 431-454.

BRooks C. K. and RUCKLIDGE J. C. (1973) A Tertiary lamprophyre dike with high pressure xenoliths and megacrysts from Wiedermanns Fjord, East Greenland. Contrib. Mineral. Petrol. 42, 197212.

Carlson R. L., Christiensen N. I. and Moore R. P. (1980) Anomalous crustal structure in ocean basins: continental fragments and oceanic plateaus. Earth Planet. Sci. Lett. 51, 171-180.

Clayton R. N. and Mayeda T. K. (1963) The use of bromine pentafluoride in the extraction of oxygen from oxides and silicates for oxygen isotopic analyses. Geochim. Cosmochim. Acta 27, 4352.

Coleman P. J. (1976) A re-evaluation of the Solomon Islands as an arc system. UN Fcon. Social Committee Asia and the Pacific, Committee for Co-ordinating Joint Prospecting for Mineral Resources, South Pacific Offshore Areas (CCOP/SOPAC). Tech. Bull. $2,140-235$.

Cox K. G. (1983) The Karoo Province of southern Africa: origin of trace element enrichment patterns. In Continental Basalts and Mantle Xenoliths (eds. C. J. HAWKESWORTH and M. J. NORRY), pp. 139-157. Shiva Publishing, UK.

DaNChIN R. V., Ferguson J., MCIVER J. R. and Nixon P. H. 
(1975) The composition of late-stage kimberlite liquids as revealed by nucleated autoliths. Phys. Chem. Earth 9, 235-245.

DAvis G. L. (1977) The ages and uranium contents of zircon from kimberlites and associated rocks. Ext. Abstr. 2nd Intl. Kimberlite Conf. Santa Fe.

DAWSON J. B. (1980) Kimberlites and Their Xenoliths. Springer Verlag, New York, 252p.

Dawson J. B., DeLaney J. S. and SMTTH J. V. (1978) Aspects of the mineralogy of alnöitic breccia, Malaita, Solomon Islands: comparisons with continental kimberlite. Contrib. Mineral. Petrol. 67, 189-193.

DEPAOLO D. J. (1981) Trace element and isotopic effects of combined wallrock assimilation and fractional crystallization. Earth Planet. Sci. Lett. 53, 189-202.

EGGLER D. H. (1978) The effect of $\mathrm{CO}_{2}$ upon partial melting of peridotite in the system $\mathrm{Na}_{2} \mathrm{O}-\mathrm{CaO}-\mathrm{Al}_{2} \mathrm{O}_{3}-\mathrm{MgO}-\mathrm{SiO}_{2}-\mathrm{CO}_{2}$ to 34 kbar, with an analysis of melting in peridotite $-\mathrm{H}_{2} \mathrm{O}-\mathrm{CO}_{2}$ systems. Amer. J. Sci. 278, 305-343.

EHRENBERG S. N. (1982) Rare earth element geochemistry of garnet therzolite and megacrystalline nodules from minettes of the Colorado Plateau province. Earth Planet. Sci. Lett. 57, 191-210.

FrANz G. W. (1965) Melting relationships in the system CaO-MgO$\mathrm{SiO}_{2}-\mathrm{CO}_{2}-\mathrm{H}_{2} \mathrm{O}$ : A study of synthetic kimberlites. $\mathrm{Ph}$.D. thesis, Pennsylvania State Univ.

Fraser K. J., Hawkesworth C. J., Erlank A. J.. Mitcheli. R. H. and SCoTT-SMITH B. H. (1985) Sr, Nd, and $\mathrm{Pb}$ isotope and minor element geochemistry of lamproites and kimberlites. Earth Planet. Sci. Lett. 76, 57-70.

FreY F. A., GreEN D. H. and Roy S. D. (1978) Integrated models of basalt petrogenesis: A study of quartz tholeittes to olivine melil itites from SE Australia utilizing geochemical and experimental petrological data. J. Petrol. 19, 463-513.

Furomoto A. S., WebB J. P., ODEGARd M. E. and IIUSSONG D. M. (1976) Seismic studies on the Ontong Java Plateau, 1970. Tectonophysics 34, $71-90$.

Gerkrts E. (1965) A visit to Malaita Island, 1962. British Solomon Islands Geol. Rec. II, 1959-1962.

Graham C. M. and Harmon R. S. (1983) Stable isotope evidence on the nature of crust-mantle interactions. In Continental Basalts and Mantle Xenoliths (eds. C. J. HAWKESWORTH and M. J. NORRY), pp. 20-45. Shiva Publishing, UK.

GREEN H. W. and GUEGUEN Y. (1974) Origin of kimberlitic pipes by diapiric upwelling in the upper mantle. Nature 249, 617-619.

GREGORY R. T. and TAYLOR H. P., JR. (1981) An oxygen isotope profile in a section of Cretaceous oceanic crust, Samail ophiolite, Oman: evidence for $\delta^{18} \mathrm{O}$ buffering of the oceans by deep $(>5 \mathrm{~km})$ seawater-hydrothermal circulation at mid-ocean ridges. J. Geophys. Res. 86, 2737-2755

Grutzeck M., Kridelbaugh S. and Weill D. (1974) The distribution of Sr and REE between diopside and silicate liquid. Geophys. Res. Lett. 1, 273-275.

GURNEY J. J., JAKOB W. R. O. and DAWSON J. B. (1979) Megacrysts from the Monastery kimberlite pipe, South Africa. In The Mantle Sample: Inclusions in Kimberlites and Other Volcanics (eds. F. R. BOyD and H. O. A. MEYER); Proc. 2nd Intl Kimberlite Conf. Santa Fe, pp. 227-243. American Geophysical Union.

HaGgerty S. E., HaRdie R. B., III and MCMAHON B. M. (1979) The mineral chemistry of ilmenite nodule associations from the Monastery diatreme. In The Mantle Sample: Inclusions in Kimberlites and Other Volcanics (eds. F. R. BOYD and H. O. A. MEYER) Proc. 2nd Intl Kimberlite Conf., Santa Fe, pp. 249-256. American Geophysical Union.

HANSON G. N. (1980) Rare earth elements in petrogenetic studies of igneous systems. Ann. Rev. Earth Planet. Sci. 8, 371-406.

HARRIS P. G. (1957) Zone refining and the origin of potassic basalts. Geochim. Cosmochim. Acta 12, 195-208.

HARkIS P. G. (1974) Origin of alkaline magmas as a result of anatexis. In The Alkaline Rocks (ed. H. SORENSON), pp. 427-436. J. Wiley \& Sons.

HARRIS P. G. and MidDlemost E. A. K. (1969) The evolution of kimberlites. Lithos 3, 77-88.
HARTE B. and CIIRNEY I. 1. (1981) The mode of formation of chro. mium-poor megacryst suites from kimberlites. $J$. Geology 89, 749753.

HouTz R. E. and EwING J. (1976) Upper crustal structure as a func tion of plate age. J. Geophys, Res. 81, 2490-2498.

HUMPHRIS S. E. and THOMPSON G. (1978) Trace element mobility during hydrothermal alteration of oceanic basalts. feochm. $\ell$ i mochim. Acta 42, 127-136

HUNTER R. H. and TAYLOR L. A. (1984) Magma mixing in the low velocity zone: Kimberlitic megacrysts from Fayette County, Pennsylvania. Amer. Mineral 69, 16-29.

HUSSONG D. M. WippermaN L. K. and Kroenke L. W. (1979) The crustal structure of the Ontong Java and Manihiki ocean plateaus. J. Geophys. Res. 84, 6003-6010.

IRVING A. J. (1974) Megacrysts from the newer basalts and other basaltic rocks of south-eastern Australia. Geol. Soc. Amer, Bull. $85,1503-1514$.

IRviNG A. J. and FreY F. A. (1978) Distribution of trace elements between garnet megacrysts and host volcanic liquids of kimberlitic to rhyolitic composition. Geochm. Cosmochim .4cta 42, 771. 787.

IRVING A. J. and FreY F. A. (1984) Trade element abundances in megacrysts and their host basalts: Constraints on partition coeffcients and megacryst genesis. Goochim. Cosmochim. Acta 48, 1201 $122 !$.

JONES R. A. (1984) Geochemical and isotopic studies of some kimberlites and included ultrabasic xenoliths from southern Africa Ph.D. thesis, Univ. of Leeds.

KAY R. W. and GAST P. W. (1973) The rare earth content and origin of alkali-rich basalts. $J$. Geology 81, 653-682.

KELEMEN P. B. (1986) Assimilation of ultramafic rock in subductionrelated magmatic ares. J. Geology 94, 829-843.

KUSHIRO I. (1979) Fractional crystallization of a basaltic magma. In The Evolution of the Igneous Rocks, Fiftieth Anniversary Perspectives (ed. H. S. YODER, JR.), pp. 171-202. Princeton Univ. Press.

KYSER T. K., ONEIL J. R. and CAR MICHAEL I. S. E. (1981) Oxygen isotope thermometry of basic lavas and mantle nodules. Contrib. Mineral. Petrol. 77, $11-23$.

KYSER T.K., O'NEUL J, R. and CARMiCHAEL 1. S. E. (1982) Genetic relations among basic lavas and ultramafic nodules: evidence from oxygen isotope compositions. Contrib. Mineral. Petrol. 81, 88102 .

LEBlanC M., DAUTIRA 1. M. and Girod M. (1982) Magnesian ilmenite xenoliths in a basanite from Tahalra, Ahaggar (southern Algeria). Contrib. Mineral Petrol. 79, 347-354.

LINDSLEY D. H. and ANDERSEN D. J. (1982) A two-pyroxene thermometer. J. Geophys. Res. 88, A887-A906.

LINDSLEY D. H. and DIXON S. A. (1976) Diopside-enstatite equilibria at $850^{\circ} \mathrm{C}$ to $1400^{\circ} \mathrm{C}, 5-35 \mathrm{Kbar}$. Amer. J. Sci. 276, $1285-1301$.

LLOYD F. E and BAILEY D. K. (1975) Light element metasomatism of the continental mantle: the evidence and the consequences. Phys. Chem. Earth 9, 389-416.

LUDDEN J. N. and THOMPSON G. (1979) An evaluation of the behaviour of the rare earth elements during the weathering of seafloor basalt. Earth Planet. Sci. Lett. 43, 85-92.

MACGREOUR I. D. (1974) The system $\mathrm{MgO}-\mathrm{Al}_{2} \mathrm{O}_{3}-5 \mathrm{SiO}$ : Solubility of $\mathrm{Al}_{2} \mathrm{O}_{3}$ in enstatite for spinel and garnet peridotite compositions. Amer. Mineral. 59, $110-119$.

MCCulloch M. T., Gregory R. T., Wasserburg G. J. and TAYLOR H. P. JR. (1981) Sm+Nd, Rb-Sr, and ${ }^{18} \mathrm{O} /{ }^{16} \mathrm{O}$ isotopic systematics in an oceanic crustal section: evidence from the Samail ophiolite. J. Geophys. Res, 86, $2721-2735$.

MCGETCHIN T.R. and BESANCON J. R. (1973) Carbonate inclusions in mantle-derived pyrope. Earth Planet. Sci. Lett. 18, 408-410.

Menzies M. A. and HAWkesworth C. J. (1987) Mantle Metasomatism. Academic Press, London. 472p.

MENZIES M. A. and MURTHY V.R. (1980) Mantle metasomatism as a precursor to the genesis of alkaline magmas-isotopic evidence. Amer. J. Sci. 280A, 622-638.

MITCHELL R. H. (1977) Geochemistry of magnesian ilmenites from kimberlites from South Africa and Lesotho. Lithos 10, 29-37. 
MITCHELL R. H. (1979) The alleged kimberlite-carbonatite relationship: additional contrary mineralogical evidence. Amer. J. Sci. 279, 570-589.

MrTCHEL1 R. H. (1986) Kimberlites: Mineralogy, Geochemistry, and Petrology. Plenum Press, New York. 442p.

MUEHLENBACHS K. (1986) Alteration of the oceanic crust and the $\delta^{18} \mathrm{O}$ history of seawater. In Stable Isotopes in High Temperature Geological Processes (eds. J. W. VALLEX, H. P. TAYLOR JR. and J. R. O'NeIL); Rev. in Mineral., 16, pp. 425-444. Mineral. Soc. Amer.

NEAL C. R. (1985) Mantie studies in the western Pacific and kimberlite-type intrusives. Ph.D. thesis, Univ. of Leeds.

NEAL C. R. (1988) The origin and composition of metasomatic fluids and amphiboles beneath Malaita, Solomon Islands. J. Petrol. 29 , $149-179$.

NEAL C. R. and TAYLOR L. A. (1989) A negative Ce anomaly in a peridotite xenolith: Evidence for crustal recycling into the mantle or mantle metasomatism? Geochim. Cosmochim. Acta 53, 10351040.

NIXON P. H. (1980) Kimberlites in the SW Pacific. Nature 287, 718720.

NIXON P. H. and BOYD F. R. (1973a) The discrete nodule (Megacryst) association in kimberlites from northern Lesotho. In Lesotho Kimberites (ed. P. H. NixON), pp. 67-75. Lesotho National Dev. Corp.

NixON P. H. and BoyD F. R. (1973b) The Liqhobong intrusions and kimberlite olivine composition. In Lesotho Kimberlites (ed. P. H. Nixon), pp. 141-148. Lesotho National Dev, Corp.

NixON P. H. and COLEMAN P. J. (1978) Garnet-bearing lherzolites and discrete nodule suites from the Malaita alnöite, Solomon Islands, and their bearing on the nature and origin of the Ontong Java Plateau. Bull. Aust. Soc. Expl. Geophys. 9, 103-107.

NIXON P. H. and NEAL. C. R. (1987) Ontong Java Plateau: Deepseated xenoliths from thick oceanic lithosphere. In Mantle Xenotiths (ed. P. H. NIXON), pp. 335-345. J. Wiley \& Sons.

Nixon P. H., Mitchell R. H. and Rogers N. W. (1980) Petrogenesis of alnöitic rocks from Malaita, Solomon Islands, Melenesia. Mineral. Mag. 43, 587-596.

NORRY M. J. and FITTON J. G. (1983) Compositional differences between oceanic and continental basic lavas and their significance. In Continental Basalts and Mantle Xenoliths (eds. C. J. HAwKEsWORTH and M. J. NORRY), pp. 5-19. Shiva Publishing, UK

O'HARA M. J. and YODER H. S. (1967) Formation and fractionation of basic magma at high pressurc. Scottish $J$, Geol. 3, 67-117.

OLAFSSON M. and EGGLER D. H. (1983) Phase relations of amphibole, amphibole-carbonate, and phlogopite-carbonate peridotite: petrologic constraints on the asthenosphere. Earth Planet. Sci. Lett. 64, 305-315.

Pasteris J. D., Boyd F. R. and Nixon P. H. (1979) The ilmenite association at Frank Smith Mine, RSA. In The Mantle Sample: Inclusions in Kimberlites and Other Volcanics, (eds. F. R. BOYD and H. O. A. MEYER); Proc. 2nd Intl. Kimberite Conf., Santa Fe. pp. 265-278. American Geophysical Union.

PEARCE J. A. and CANN J. R. (1973) Tectonic setting of basic volcanic rocks determined using trace element analyses. Earth Planet. Sci. Lett. 19, 290-300.

PHILPOTTS J. A. and SCHNETZLER C. C. (1970) Phenocryst-matrix partition coefficients for $\mathrm{K}, \mathrm{Rb}, \mathrm{Sr}$, and $\mathrm{Ba}$, with application to anorthosite and basalt petrogenesis. Geochim. Cosmochim. Acta 34, 307-322.

Rickwood F. K. (1957) Geology of the island of Malaita. Colon. Geol. Mineral Res. 6, 300-305.

Rock N. M. S. (1986) The nature and origin of ultramafic lamprophyres: alnöites and allied rocks. J. Petrol 27, 155-196.

ROSENBUSCH H. (1887) Mikroskopische Physiographie, 2nd edn. Schweizerbart, Stuttgart, 805p.

RuBENSTONE J. L. and ZINDLER A. (1989) Isotopic variation in the sub-Pacific mantle: Inferences from Malaita peridotites. Earth Planet. Sci. Lett. (in press).

SChNetzler C. C. and PHilpotts J. A. (1970) Partition coefficients of REE between igneous matrix material and rock-forming phenocrysts-II. Geochim. Cosmochim. Acta 34, 331-340.

SCHULZE D. J. (1984) Cr-poor megacrysts from the Hamilton Branch kimberlite, Elliot County, Kentucky. In Kimberlites II: The Mantle and Crust-Mantle Relationships (ed. J. KorNProBst); Proc. 3rd Intl. Kimberlite Conf, pp. 97-108. Elsevier.

SCHULZE D. J. and HOOVER J. D. (1982) Origin of compositional trends in megacrysts from kimberlites by fractional crystallization (abstr.). Eos 63, 464.

SHIMUZU N. (1975) REE in gamet and clinopyroxene from garnet lherzolite nodules in kimberlite. Earth Planet. Sci. Lett. 25, 2632.

SHIMUZU N. and KUSHIRO I. (1975) The partitioning of REE between garnet and liquid at high pressures: preliminary experiments. Geophys. Res. Lett. 2, 413-416.

SHERVAIS J. W., TAYLOR L. A. and LAUL J. C. (1987) Magma mixing and kimberlite genesis: Mineralogic, petrologic, and trace element evidence from eastern U.S.A. kimberlites. Geol. Soc. Amer. Spec. Pap. 215, 101-114.

SPERA F.J. (1984) Carbon dioxide in petrogenesis III: Role of volatiles in the ascent of alkaline magma with special reference to xenolithbearing mafic lavas. Contrib. Mineral. Petrol. 88, $217-232$.

STAIDIGFI. H., HART S. R. and RICHARDSON S. H. (1981) Alteration of the oceanic crust: Process and timing. Earth Planet. Sci. Lett. 52, 311-327.

TAYLOR W. R. and GREEN D. H. (1986) The role of reduced C-OH fuids in mantle partial melting. Geol. Soc. Australia, 16; 4th Intl. Kimberlite Conf, Perth, pp. 211-213.

THIRLWALL M. F. (1982) A triple filament method for rapid and precise analysis of rare earth elements by isotope dilution. Chem. Geology 35, 155-166.

THOMPSON R. B. (1965) A visit to Malaita Island, 1962. Brit. Solomon Islands Geol. Record 1959-1962 II, 141-142.

Thompson R. N. (1974) Primary basalts and magma genesis. I. Skye, northwest Scotland. Contrib. Mineral. Petrol. 45, 317-341.

Weiblen P. W., Stuckless J. S., Hunter W. C., Schulz K. J and MUDREY M. G., JR. (1981) Correlations of clinopyroxene compositions with environment of formation based on data from Ross Island volcanic rocks. Antarctic Res. Series 33, 229-246.

WYLLIE P. J. (1980) The origin of kimberlite. J. Geophys. Res. 85, $6902-6910$

WYLLIE P. J. (1986) Genesis and migration of kimberlites and other low-SiO ${ }_{2}$, high alkali magmas. Geol. Soc. Austr. 16; 4 th Intl. Kimberlite Conf., Perth, pp. 214-216.

WYLLE P. J. (1987) Discussion of recent papers on carbonated peridotite, bearing on mantle metasomatism and magmatism. Earth Planet. Sci. Lett. 82, 391-397.

YODER H. S., JR. and TILLEY C. E. (1962) Origin of basalt magmas: An experimental study of natural and synthetic rock systems. $J$. Petrol. 3, 342-532.

\section{APPENDIX: ANALYTICAL METHODS}

Major and trace element whole-rock compositions were determined on fused disks and pressed powder pellets, respectively, using a Philips PW1400 X-ray luorescence spectrometer. Running parameters for major elements were $40 \mathrm{kV}, 60 \mathrm{~mA}$, whereas trace elements were analyzed at $50 \mathrm{kV}, 50 \mathrm{~mA}$. Errors are approximately $5-10 \%$ for trace clements and $\pm 1 \%$ of the measured value for major elements.

Major element mineral analyses were conducted on a JEOL-50A electron microprobe fitted with an energy dispersive system (Link 860 Series 2). Errors are generally $\pm 2 \%$ of the measured value, except for sodium which is $\pm 10 \%$. In order to decrease the analytical errors, each reported composition is an average of at least ten individual analyses (where minerals are homogeneous).

Ultrapure mineral separates of the megacrysts were prepared by progressive leaching in $\mathrm{HCl}, \mathrm{HNO}_{3}$, and $\mathrm{HF}$ acids with repeated handpicking. These and whole-rock alnöite samples were analyzed by isotope dilution for the REE (and $\mathrm{Sr}, \mathrm{Nd}$ and $\mathrm{O}$ isotopes). The 
REE were separated on ion exchange columns after dissolution and measured automatically on a VG Isomass $54 \mathrm{E}$ spectrometer, using the method of ThIRLWALL (1982). The terms "depleted" and "enriched" are used to describe REE patterns relative to a flat, chondritenormalized bulk earth pattern.

Mineral separates and whole-rock alnöite samples for $\mathrm{Sr}, \mathrm{Nd}$, and $O$ isotope analysis were prepared as for REE analysis. Sr and $\mathrm{Nd}$ were separated on ion exchange columns and loaded on triple filaments (rhenium center, tantalum sides) for Nd analysis, and on single tantalum filaments for $\mathrm{Sr}$ analysis. The analyses reported here were included in a much larger study of the Malaitan alnöite (see NEAL, 1985, for a full discussion of the procedure used). External precision over the period of study was monitored by running standard samples. For Nd, 16 measurements of the La Jolla standard gave a ${ }^{143} \mathrm{Nd}$ / ${ }^{144} \mathrm{Nd}$ ratio of $0.511889 \pm 20$. A fractionation correction is applied to $\mathrm{Nd}$ measurements, using the ${ }^{146} \mathrm{Nd} /{ }^{144} \mathrm{Nd}$ ratio of 0.7219 . For $\mathrm{Sr}$, 38 measurements of the NBS 987 standard gave an average ${ }^{87} \mathrm{Sr} /{ }^{86} \mathrm{Sr}$ ratio of $0.710281 \pm 4$. Where needed, all isotopic ratios have been corrected to the age of eruption ( $34 \mathrm{Ma}$; DAVIS, 1977)

Oxygen was extracted from clinopyroxene megacrysts using techniques similar to those described by CLAYTON and MAYEDA (1963). but employing $\mathrm{ClF}_{3}$ as an alternative reagent (BORTHWICK and HARMON, 1982). Oxygen isotope ratios were measured on a Finnegan MAT 251 triple collector gas source mass spectrometer, and are reported as delta values relative to SMOW. Internal precision is estimated at better than $0.1 \%$. Analyses were repeated two or three times with reproducibility generally better than $0.2 \%$. Whe' two of the three results were in obvious agreement, the spurious value was discarded. These spurious analyses usually coincided with extraction problems such as low gas yields. The two analyses of CRN199 are $0.35 \%$ different, but insufficient sample was available to perform further measurements. Although PHN3889 was analyzed several times, reproducibility was poor, indicating some problem with sample heterogeneity or purity. 